\title{
The discovery of new mineral species and type minerals from Brazil
}

\author{
A descoberta de novas espécies minerais e minerais tipo do Brasil
}

\author{
Daniel Atencio ${ }^{1 *}$
}

RESUMO: Os minerais foram vistos apenas como fontes de produtos químicos: minério de ferro, minério de cobre, etc. No entanto, não são apenas associações de elementos químicos, uma vez que apresentam estruturas cristalinas. Essas duas características em conjunto proporcionam propriedades que podem ser tecnologicamente úteis. Mesmo que um mineral ocorra em quantidade muito pequena, o que não permite a sua extração, pode servir como um modelo para a obtençấo do análogo sintético em uma escala industrial. É necessário que uma proposta de novo mineral seja submetida à aprovação pela Comissão de Novos Minerais, Nomenclatura e Classificação (CNMNC) da Associaçáo Mineralógica Internacional (IMA) antes da publicação. Somente 65 espécies minerais válidas foram descritas pela primeira vez no Brasil, isto é, minerais-tipo do Brasil. Dezenove delas foram publicadas entre 1789 e $1959(0,11$ por ano). De 1959, quando a CNMMN (hoje CNMNC) - IMA foi criada, até 2000, 18 espécies minerais brasileiras aprovadas permanecem válidas (0,43 por ano). No entanto, o número de minerais-tipo do Brasil aprovados nos últimos 15 anos $(2000$ - 2014) foi substancialmente maior: 28 ( 1,87 por ano). Esse número é muito pequeno considerando a grande variedade de ambientes geológicos brasileiros. As duas primeiras espéciestipo do Brasil, descobertas no século 18, crisoberilo e euclásio, são importantes minerais gemológicos. Dois outros minerais-gema, membros do supergrupo da turmalina, foram publicados apenas no século 21: uvita e fluor-elbaíta. Alguns minerais-tipo do Brasil são muito importantes tecnologicamente falando. Alguns exemplos são menezesita, coutinhoíta, lindbergita, pauloabibita e waimirita-(Y).

PALAVRAS-CHAVES: Minerais novos; Minerais-tipo; Descrição mineralógica; Brasil.

\begin{abstract}
Minerals were seen merely as sources of chemicals: iron ore, copper ore, etc. However, minerals are not just chemicals associations, since they display crystal structures. These two features together provide properties that can be technologically useful. Even though a mineral occurs in very small amount, which does not allow its extraction, it can serve as a model for obtaining the synthetic analogue on an industrial scale. It is necessary that a new-mineral proposal be submitted for approval by the Commission on New Minerals, Nomenclature and Classification (CNMNC) of the International Mineralogical Association (IMA) before publication. Only 65 valid mineral species were first described from Brazil, that is, the type minerals from Brazil. Nineteen of these were published between 1789 and 1959 (0.11 per year). From 1959, when the CNMMN (today CNMNC) - IMA was established, to 2000, 18 approved Brazilian mineral species remain valid ( 0.43 per year). However, the number of type minerals from Brazil approved in the last 15 years (2000 to 2014) was substantially increased: 28 (1.87 per year). This number is very small considering the wide range of Brazilian geological environments. The two first type species from Brazil, discovered in the $18^{\text {th }}$ century, chrysoberyl and euclase, are important gemological minerals. Two other gem minerals, tourmaline-supergroup members, were published only in the $21^{\text {st }}$ century: uvite and fluor-elbaite. Some type minerals from Brazil are very important technologically speaking. Some examples are menezesite, coutinhoite, lindbergite, pauloabibite, and waimirite- $(Y)$.
\end{abstract}

KEYWORDS: New mineral; Type mineral; Mineralogical description; Brazil.

${ }^{1}$ Mineralogy and Geotectonics Department, Geosciences Institute, Universidade de São Paulo - USP, São Paulo (SP), Brazil. E-mail: datencio@usp.br ${ }^{*}$ Corresponding author.

Manuscrito ID: 30242. Recebido em: 30/12/2014. Aprovado em: 19/02/2015. 


\section{INTRODUCTION}

The description of a new mineral species requires scientific and intellectual ability in order to obtain data from a wide variety of experimental — classical and modern methods. In general, we tend to think only in minerals in mineralogical terms, instead of considering them in the broader context of inorganic materials. Some new minerals are also new compounds. Because of their chemical composition and crystal structure, some new minerals have interesting properties, whether physical, electronic, optical or magnetic, which have applications in technology. According to Khomyakov (2001), although the great majority of these will be mineralogical rarities, the identification and study of the yet undescribed natural phases is not only of interest from a purely scientific point of view but also has practical implications. Among the future minerals, there will undoubtedly be various types of commercial ores and compounds with unique structures and technologically useful properties. Having a broader view of our study material, we can explore our findings more fully and, at the same time, raise the scientific profile of descriptive mineralogy.

In the past, minerals were seen, in general, merely as sources of chemicals: iron ore, copper ore, etc. However, minerals are not just chemicals associations, since they display crystal structures. These two features together provide properties that can be technologically useful. Even though the mineral occurs in very small amount, which does not allow its extraction, it can serve as a model for obtaining the synthetic analogue on an industrial scale.

In this work we will present some data and comments for the type minerals from Brazil. A table will indicate chemical formula, crystallographic system and references for the 65 mineral species that were first described from Brazil.

\section{THE CONCEPT OF A MINERAL SPECIES}

The current official definition of mineral is due to Nickel and Grice (1998). A mineral species is a naturally occurring solid that has been formed by geological processes, either on earth or in extraterrestrial bodies, with well-defined chemical composition and crystallographic properties, and which merits a unique name. It is defined mainly on the basis of chemical composition and crystallographic properties, and these must therefore be the key factors in determining whether the creation of a new mineral species and a new mineral name is justified. Nevertheless, especially over the last 20 years, the reported definitions of a mineral, as stated in introductory geoscience- and mineralogy-related textbooks and online, generally have become progressively broader and more detailed (Caraballo et al. 2015). To some extent, this is likely due to advancement of the mineralogical sciences that is, in part, driven by new characterization tools and methods, and also by an increase in scientists who are interested in minerals. Recently, French et al. (2012) compiled up-to-date authoritative descriptions of the term mineral, producing the following definition: currently, minerals are most commonly defined as naturally occurring substances, produced by (bio)geochemical processes, with a highly ordered, repeating atomic arrangement (a crystalline substance) whose composition can be described by a chemical formula that is either fixed or variable (or, also as often stated, a definite, but not necessarily fixed, composition). Samples of the same mineral vary in terms of minor and/or trace element composition, and in the case of solid solution, major element composition, as long as these substitutions do not change the average crystal structure. Finally, it follows that minerals of the same major and minor element composition will express a set of measureable and consistent physical and chemical properties. If a mineral whose composition or crystallographic properties (or both) are substantially different from those of any existing mineral species is found, there is a possibility that it may be a new species.

The Commission on New Minerals, Nomenclature and Classification (CNMNC) of the International Mineralogical Association (IMA) was formed in July 2006 by a merger between the Commission on New Minerals and Mineral Names (CNMMN) and the Commission on Classification of Minerals (CCM).

The CNMMN was established in 1959 for the purpose of controlling the introduction of new minerals and mineral names, and of rationalizing mineral nomenclature. Since that time, the work of the CNMMN has gained overwhelming support from the international mineralogical community. The objective of the CCM was to review existing systems of mineral classification and to provide advice on the classification of minerals to the mineralogical community. The CNMNC consists of representatives appointed by national mineralogical bodies and an executive committee consisting of chairman, two vice-chairmen and secretary. An official IMA-CNMNC list of Mineral Names can be accessed on the IMA web site.

The founding of the CNMMN marked a turning point in the history of mineral nomenclature (Fourestier 2002). Up until that time, the naming of minerals had been a haphazard and inexact aspect of our science at best. This new commission had the mandate to put order into many centuries of conflicting and divergent methods of giving names to naturally occurring chemical substances. There clearly had been less-than-adequate agreement on what constituted a 
mineral. In fact, many mixtures of minerals and most biogenic substances, such as amber or coal, were included in early treatises on minerals.

\section{THE DESCRIPTION OF A NEW MINERAL}

A new mineral!? What to do? - The following information is from the IMA-CNMNC site: "Researchers finding a phase of which they think that it might be a new mineral are encouraged to use the following procedure in order to get it approved by the IMA-CNMNC. Please read carefully the procedures and guidelines of the IMA-CNMNC on the criteria for a new mineral species and the treatment of a new-mineral proposal. Please also consult these procedures and guidelines if proposing changes to existing nomenclature. If the possibility of a new mineral still stands after reading the procedures and guidelines, please download the checklist for new-mineral proposals. Provide the data asked for, as far as possible. Send the completed checklist (preferably in electronic format) to the CNMNC chairman. Send proposals to change existing nomenclature to the CNMNC vice-chairman."

It is necessary that a new-mineral proposal be submitted for approval by the CNMNC before publication. Such a submission should contain as much information as possible so that the Commission can adequately judge the validity of the proposal (Nickel \& Grice 1998). Ideally, a new-mineral proposal should contain information quoted in Chart 1.

It is recognized that it may not always be possible to obtain all these data; in such cases, the author should give reasons for the omissions. Of particular importance is the calculation of $\mathrm{H}_{2} \mathrm{O}$ content in which it has not been determined analytically. If $\mathrm{H}_{2} \mathrm{O}$ is reported by difference, the method of calculation should be clearly stated and, if possible, evidence for the presence of $\mathrm{H}_{2} \mathrm{O}$ should be provided. Also, ample justification should be given for the allocation of hydrogen to $\mathrm{H}_{2} \mathrm{O}, \mathrm{OH}$ or $\mathrm{H}_{3} \mathrm{O}$. Because of great differences in the amount and type of information that can be obtained from the study of a particular mineral specimen, it is not practical to specify the irreducible minimum of information required for a mineral to be approved; each proposal must be considered on its own merits (Nickel \& Grice 1998).

\section{Chart 1. Data for a new mineral nomenclature proposal}

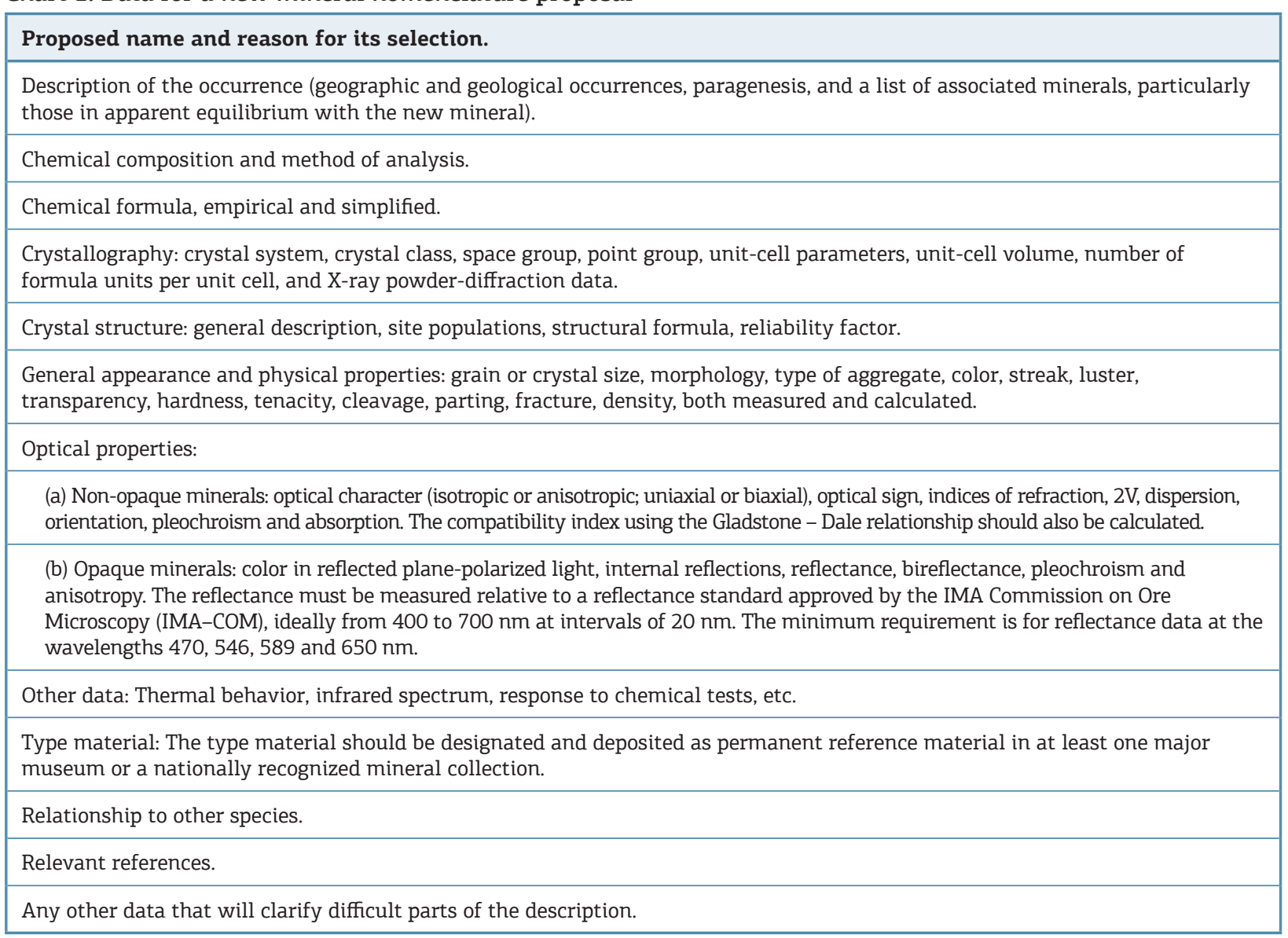


The mineral species in the latest official IMA-CNMNC list (September 2014) are 4,963, including 99 questionable minerals. The development of mineralogy in the latter half of the $20^{\text {th }}$ century has been marked by an accelerating pace of new mineral discoveries. The number of minerals discovered worldwide since 1970 is roughly equal to that recorded throughout the preceding historic time (Khomyakov 2001). Skinner and Skinner (1980) concluded that there are no predictable limits to the number of minerals. According to the predictions of Khomyakov (1998a, b) based on correlation diagrams (the number of species versus time), the total number of known minerals will approach 11,000 by the year 2050. In this century (from 2001 to 2014), 1,180 new minerals proposals were handled by the CNMNC, a mean of 84,3 proposals per year. On the other hand, the number of artificial compounds with a specific chemistry and specific properties amounts to many millions.

The long-held thesis that there is a limit to the number of mineral species is valid only for ordinary types of rocks and mineral deposits. The principal sources of new mineral discoveries are deposits formed in anomalous geotectonic and geochemical environments under conditions that virtually encompass the entire range of physicochemical parameters accessible to modern experimental mineralogy and, moreover, include geological time and other factors unattainable experimentally in the laboratory. All this serves to remove any barriers that limit the number of mineral species (Khomyakov 2001).

\section{MINERAL SPECIES FIRST DESCRIBED FROM BRAZIL}

Of the nearly 5,000 known mineral species, only 65 were first described from Brazil, that is, the type minerals from Brazil (Table 1).

Nineteen of these were published between 1789 and 1959 (0.11 per year). From 1959, when the CNMMN (today CNMNC) - IMA was established, to 2000, 18 approved Brazilian mineral species remain valid ( 0.43 per year). However, the number of type minerals from Brazil approved in the last 15 years (2000 to 2014) was substantially increased: 28 (1.87 per year). Nevertheless, this number is very small when considering the wide range of Brazilian geological environments.

Comparing with other parts of the world, we can mention that in several very specific individual locations in various countries, much more new species were described than in Brazil, for example:

- The alkaline Khibiny massif in the Kola Peninsula, Russia: 116 new species were described.
Iron and manganese mine Långban in Sweden: 71 new minerals are listed.

- Franklin Mining District, Sussex Co., New Jersey, USA: 71 new species defined.

- Tsumeb, Otjikoto Region (Oshikoto), Namibia: 71 new species detected.

- Nepheline syenite of Mont Saint-Hilaire, Quebec, Canada: 62 new species.

Finally, within the Italian territory, much smaller than Brazil, 312 new species were discovered. These figures illustrate that there has been a neglect of the Brazilian Geological and Mining sectors at all levels (mining companies, DNPM, universities, geologists and mining engineers) with respect to the knowledge of mineralogy of the deposits; mineral species of high scientific and commercial value and new mineral species are probably being destroyed without having the opportunity to be known.

In addition, in his review on Brazilian mineral species, Atencio (2000) listed several problems noted in the description of Brazilian minerals:

1. Several names were introduced and used without adequate justification and also without IMA approval.

2. Several minerals first described as new species were later discredited as misidentifications or as varieties of existing minerals.

3. There are many incompletely described and consequently unnamed minerals waiting for additional studies.

4. Several relevant papers were published in practically inaccessible sources.

5. Several type specimens were not preserved in museums.

Table 2 presents the 65 mineral species first described from Brazil, their chemical formula, crystallographic system and references. Phosphates are predominant (24), followed by oxides (17) and silicates (8). A few selected specimens will be presented in Plates 1 to 4 . Among the phosphates, we highlight 4 roscherite-group members [zanazziite, atencioite (Fig. 1B), ruifrancoite (Fig. 4C), and guimarãesite (Fig. 2D)]. Among the oxides, there are 5 pyrochlore-supergroup minerals [hydroxycalcioroméite, fluornatromicrolite, hydrokenomicrolite (Fig. 3A), fluorcalciomicrolite and hydroxycalciomicrolite (Fig. 3B)], 2 senaite-group minerals [senaite and almeidaite (Fig. 1A)] and 1 niobate [carlosbarbosaite (Fig. 2A)]. Among the silicates, we can quote 2 alkaline rock minerals, manganoeudialyte (Fig. 3D) and fluorlamprophyllite, both from Poços de Caldas, Minas Gerais. As a matter of curiosity, there are $2 \mathrm{Fe}^{2+}-\mathrm{Fe}^{3+}$ arsenates, bendadaite (Fig. 1C) and césarferreiraite (Fig. 2B), and 1 telurate [brumadoite (Fig. 1D)]. 
Table 1. Type minerals from Brazil

\begin{tabular}{|c|c|c|c|c|}
\hline \multicolumn{2}{|r|}{$\begin{array}{l}\text { IMA } \\
\text { number }\end{array}$} & Mineral & Formula, crystal system & \multirow{2}{*}{$\begin{array}{c}\text { Reference } \\
\text { Karsten (1789), } \\
\text { Hoffmann(1789) }\end{array}$} \\
\hline 1 & & Chrysoberyl & $\mathrm{BeAl}_{2} \mathrm{O}_{4}$, orthorhombic & \\
\hline 2 & & Euclase & $\mathrm{BeAlSiO}_{4} \mathrm{OH}$, monoclinic & $\begin{array}{l}\text { Delamétherie (1792); Hauy } \\
\text { in Delamétherie (1797) }\end{array}$ \\
\hline 3 & & Palladium & Pd, cubic & Wollaston (1809) \\
\hline 4 & & Goyazite & $\mathrm{SrAl}_{3}\left[\mathrm{PO}_{3} \mathrm{O}_{y_{2}}(\mathrm{OH})_{y_{2}}\right]_{2}(\mathrm{OH})_{6}$, trigonal & Damour (1884) \\
\hline 5 & & Zirkelite & $(\mathrm{Ti}, \mathrm{Ca}, \mathrm{Zr}) \mathrm{O}_{2-\mathrm{x}^{\prime}}$, cubic & Hussak \& Prior (1895) \\
\hline 6 & & Derbylite & $\mathrm{Fe}_{4}^{3+}{ }_{4} \mathrm{Ti}_{3}^{4+} \mathrm{Sb}^{3+} \mathrm{O}_{13}(\mathrm{OH})$, monoclinic & Hussak \& Prior (1897a) \\
\hline 7 & & Tripuhyite & $\mathrm{Fe}^{3+} \mathrm{Sb}^{5+} \mathrm{O}_{4}$, tetragonal & Hussak \& Prior (1897b) \\
\hline 8 & & Senaite & $(\mathrm{Pb}, \mathrm{Sr}) \mathrm{Mn}\left(\mathrm{Fe}^{2+}, \mathrm{Zn}\right)_{2}\left(\mathrm{Ti}, \mathrm{Fe}^{3+}\right)_{18}(\mathrm{O}, \mathrm{OH})_{38}$, trigonal & Hussak \& Prior (1898) \\
\hline 9 & & Florencite-(Ce) & $\mathrm{CeAl}_{3}\left(\mathrm{PO}_{4}\right)_{2}(\mathrm{OH})_{6}$, trigonal & Hussak \& Prior (1900) \\
\hline 10 & & Gorceixite & $\mathrm{BaAl}_{3}\left(\mathrm{PO}_{4}\right)\left(\mathrm{PO}_{3} \mathrm{OH}\right)(\mathrm{OH})_{6}$, monoclinic & Hussak (1906) \\
\hline 11 & & Brazilianite & $\mathrm{NaAl}_{3}\left(\mathrm{PO}_{4}\right)_{2}(\mathrm{OH})_{4}$, monoclinic & Pough \& Henderson (1945) \\
\hline 12 & & Souzalite & $\mathrm{Mg}_{3} \mathrm{Al}_{4}\left(\mathrm{PO}_{4}\right)_{4}(\mathrm{OH})_{6} \cdot 2 \mathrm{H}_{2} \mathrm{O}$, triclinic & Pecora \& Fahey (1949) \\
\hline 13 & & Scorzalite & $(\mathrm{Fe}, \mathrm{Mg}) \mathrm{Al}_{2}\left(\mathrm{PO}_{4}\right)_{2}(\mathrm{OH})_{2}$, monoclinic & Pecora \& Fahey (1949) \\
\hline 14 & & Frondelite & $\mathrm{Mn}^{2+} \mathrm{Fe}_{4}^{3+}\left(\mathrm{PO}_{4}\right)_{3}(\mathrm{OH})_{5}$, orthorhombic & Lindberg (1949) \\
\hline 15 & & Faheyite & $\mathrm{Be}_{2}(\mathrm{Mn}, \mathrm{Mg}, \mathrm{Na}) \mathrm{Fe}_{2}^{3+}\left(\mathrm{PO}_{4}\right)_{4} \cdot 6 \mathrm{H}_{2} \mathrm{O}$, hexagonal & Lindberg \& Murata (1953) \\
\hline 16 & & Moraesite & $\mathrm{Be}_{2} \mathrm{PO}_{4}(\mathrm{OH}) \cdot 4 \mathrm{H}_{2} \mathrm{O}$, monoclinic & Lindberg et al. (1953) \\
\hline 17 & & Barbosalite & $\mathrm{Fe}^{2+} \mathrm{Fe}_{2}^{3+}\left(\mathrm{PO}_{4}\right)_{2}(\mathrm{OH})_{2}$, monoclinic & Lindberg \& Pecora (1955) \\
\hline 18 & & Tavorite & $\mathrm{LiFe}^{3+} \mathrm{PO}_{4}(\mathrm{OH})$, triclinic & Lindberg \& Pecora (1955) \\
\hline 19 & 1973-002a & Arsenopalladinite & $\mathrm{Pd}_{8}(\mathrm{As}, \mathrm{Sb})_{3}$, triclinic & Hey (1955) \\
\hline 20 & $1973-050$ & Atheneite & $\mathrm{Pd}_{2}\left(\mathrm{As}_{0.75} \mathrm{Hg}_{0.25}\right)$, hexagonal & Clark et al. (1974) \\
\hline 21 & $1973-057$ & Isomertieite & $\mathrm{Pd}_{11} \mathrm{Sb}_{2} \mathrm{As}_{2}$, cubic & Clark et al.(1974) \\
\hline 22 & $1974-027$ & Bahianite & $\mathrm{Al}_{5} \mathrm{Sb}_{3} \mathrm{O}_{14}(\mathrm{OH})_{2}$ to $\mathrm{Al}_{5} \mathrm{Sb}_{3}(\mathrm{Al}, \mathrm{Be}, \mathrm{Si})_{<2} \mathrm{O}_{16}$, monoclinic & Moore et al. (1978) \\
\hline 23 & 1975-001 & Whiteite-(CaFeMg) & $\mathrm{CaFe}^{2+} \mathrm{Mg}_{2} \mathrm{Al}_{2}\left(\mathrm{PO}_{4}\right)_{4}(\mathrm{OH})_{2} \cdot 8 \mathrm{H}_{2} \mathrm{O}$, monoclinic & Moore \& Ito (1978) \\
\hline 24 & 1975-001 & Whiteite-(MnFeMg) & $\mathrm{Mn}^{2+} \mathrm{Fe}^{2+} \mathrm{Mg}_{2} \mathrm{Al}_{2}\left(\mathrm{PO}_{4}\right)_{4}(\mathrm{OH})_{2} \cdot 8 \mathrm{H}_{2} \mathrm{O}$, monoclinic & Moore \& Ito (1978) \\
\hline 25 & $1975-026$ & Palladseite & $\mathrm{Pd}_{17} \mathrm{Se}_{15}$, cubic & Davis et al. (1977) \\
\hline 26 & 1979-074 & Lanthanite-(Nd) & $(\mathrm{Nd}, \mathrm{La})_{2}\left(\mathrm{CO}_{3}\right)_{3} \cdot 8 \mathrm{H}_{2} \mathrm{O}$, orthorhombic & Roberts et al. (1980) \\
\hline 27 & $1983-090$ & Minasgeraisite-(Y) & $\mathrm{BiY}_{2} \mathrm{Ca}(\mathrm{Na}, \mathrm{Li})_{2} \mathrm{Si}_{4}(\mathrm{Si}, \mathrm{Be})_{2} \mathrm{Be}_{2} \mathrm{O}_{20}$, triclinic & Foord et al. (1986) \\
\hline 28 & $1984-003$ & Parabariomicrolite & $\mathrm{BaTa}_{4} \mathrm{O}_{10}(\mathrm{OH})_{2} \cdot 2 \mathrm{H}_{2} \mathrm{O}$, trigonal & Ercit et al. (1986) \\
\hline 29 & & Lanthanite-(La) & $(\mathrm{La}, \mathrm{Nd})_{2}\left(\mathrm{CO}_{3}\right)_{3} \cdot 8 \mathrm{H}_{2} \mathrm{O}$, orthorhombic & Nickel \& Mandarino (1987) \\
\hline 30 & $1986-054$ & Zanazziite & $\begin{array}{c}\mathrm{Ca}_{2}(\square \mathrm{Mg}) \mathrm{Mg}_{4} \mathrm{Be}_{4}\left(\mathrm{PO}_{4}\right)_{6}\left[(\mathrm{OH})_{4}\left(\mathrm{H}_{2} \mathrm{O}\right)_{2}\right] \cdot 4 \mathrm{H}_{2} \mathrm{O} \\
\text { monoclinic }\end{array}$ & Leavens et al. (1990) \\
\hline 31 & 1988-008 & Arupite & $\mathrm{Ni}_{3}\left(\mathrm{PO}_{4}\right)_{2} \cdot 8 \mathrm{H}_{2} \mathrm{O}$, monoclinic & Buchwald (1990) \\
\hline 32 & 1990-052 & Yanomamite & $\mathrm{In}\left(\mathrm{AsO}_{4}\right) \cdot 2 \mathrm{H}_{2} \mathrm{O}$, orthorhombic & Botelho et al. (1994) \\
\hline
\end{tabular}


Table 1. Continuation

\begin{tabular}{|c|c|c|c|c|}
\hline & $\begin{array}{c}\text { IMA } \\
\text { number }\end{array}$ & Mineral & Formula, crystal system & Reference \\
\hline 33 & $1992-028$ & Quintinite & $\mathrm{Mg}_{4} \mathrm{Al}_{2}(\mathrm{OH})_{12}\left(\mathrm{CO}_{3}\right) \cdot 3 \mathrm{H}_{2} \mathrm{O}$, hexagonal & Chao \& Gault (1997) \\
\hline 34 & 1998-006 & Serrabrancaite & $\mathrm{Mn}^{3+} \mathrm{PO}_{4} \cdot \mathrm{H}_{2} \mathrm{O}$, monoclinic & Witzke et al. (2000) \\
\hline 35 & $1998-011$ & Fluornatromicrolite & $(\mathrm{Na}, \mathrm{Ca}, \mathrm{Bi})_{2} \mathrm{Ta}_{2} \mathrm{O}_{6} \mathrm{~F}$, cubic & Witzke et al. (2011) \\
\hline 36 & 1998-053a & Bendadaite & $\mathrm{Fe}^{2+} \mathrm{Fe}_{2}^{3+}\left(\mathrm{AsO}_{4}\right)_{2}(\mathrm{OH})_{2} \cdot 4 \mathrm{H}_{2} \mathrm{O}$, monoclinic & Kolitsch et al. (2010) \\
\hline 37 & $1999-021$ & Dukeite & $\mathrm{Bi}^{3+}{ }_{24} \mathrm{Cr}_{8}^{6+} \mathrm{O}_{57}(\mathrm{OH})_{6} \cdot 3 \mathrm{H}_{2} \mathrm{O}$, trigonal & Burns et al. (2000) \\
\hline 38 & 2000-030a & Uvite & $\mathrm{CaMg}_{3}\left(\mathrm{Al}_{5} \mathrm{Mg}\right)\left(\mathrm{Si}_{6} \mathrm{O}_{18}\right)\left(\mathrm{BO}_{3}\right)_{3}(\mathrm{OH})_{3}(\mathrm{OH})$, trigonal & Clark et al. (2010) \\
\hline 39 & $2003-025$ & Coutinhoite & $\mathrm{Th}_{0.5}\left(\mathrm{UO}_{2}\right)_{2} \mathrm{Si}_{5} \mathrm{O}_{13} \cdot 3 \mathrm{H}_{2} \mathrm{O}$, orthorhombic & Atencio et al. (2004a) \\
\hline 40 & 2003-029 & Lindbergite & $\mathrm{Mn}\left(\mathrm{C}_{2} \mathrm{O}_{4}\right) \cdot 2 \mathrm{H}_{2} \mathrm{O}$, monoclinic & Atencio et al. (2004b) \\
\hline 41 & $2004-013$ & Oxykinoshitalite & $\mathrm{BaMg}_{3}\left(\mathrm{Si}_{3} \mathrm{Al}\right) \mathrm{O}_{10} \mathrm{O}_{2}$, monoclinic & Kogarko et al. (2005) \\
\hline 42 & 2004-041 & Atencioite & $\mathrm{Ca}_{2} \mathrm{Fe}^{2+} \mathrm{Mg}_{2} \mathrm{Fe}_{2}^{2+} \mathrm{Be}_{4}\left(\mathrm{PO}_{4}\right)_{6}(\mathrm{OH})_{4} \cdot 6 \mathrm{H}_{2} \mathrm{O}$, triclinic & Chukanov et al. (2006) \\
\hline 43 & $2004-047$ & Kalungaite & PdAsSe, cubic & Botelho et al. (2006) \\
\hline 44 & $2005-011$ & Matioliite & $\mathrm{NaMgAl}_{5}\left(\mathrm{PO}_{4}\right)_{4}(\mathrm{OH})_{6} \cdot 2 \mathrm{H}_{2} \mathrm{O}$, monoclinic & Atencio et al. (2006) \\
\hline 45 & $2005-023$ & Menezesite & $\square_{12} \mathrm{Mg}_{3} \mathrm{Zr}_{4}\left(\mathrm{BaNb}_{12} \mathrm{O}_{42}\right) \cdot 12 \mathrm{H}_{2} \mathrm{O}$, cubic & Atencio et al. (2008a) \\
\hline 46 & $2005-056$ & Arrojadite-(PbFe) & $\mathrm{PbFe}^{2+} \mathrm{Na}_{2} \mathrm{CaFe}^{2+}{ }_{13} \mathrm{Al}\left(\mathrm{PO}_{4}\right)_{11}\left(\mathrm{PO}_{3} \mathrm{OH}\right)(\mathrm{OH})_{2}$, monoclinic & Chopin et al. (2006) \\
\hline 47 & $2005-061$ & Ruifrancoite & $\mathrm{Ca}_{2} \square_{2} \mathrm{Fe}_{4}^{3+} \mathrm{Be}_{4}\left(\mathrm{PO}_{4}\right)_{6}(\mathrm{OH})_{6} \cdot 4 \mathrm{H}_{2} \mathrm{O}$, monoclinic & Atencio et al. (2007) \\
\hline 48 & $2006-028$ & Guimarãesite & $\mathrm{Ca}_{2}(\square \mathrm{Zn}) \mathrm{Zn}_{4} \mathrm{Be}_{4}\left(\mathrm{PO}_{4}\right)_{6}\left[(\mathrm{OH})_{4}\left(\mathrm{H}_{2} \mathrm{O}\right)_{2}\right] \cdot 4 \mathrm{H}_{2} \mathrm{O}$, monoclinic & Chukanov et al. (2007) \\
\hline 49 & $2008-028$ & Brumadoite & $\mathrm{Cu}_{3}\left(\mathrm{Te}^{6+} \mathrm{O}_{4}\right)(\mathrm{OH})_{4} \cdot 5 \mathrm{H}_{2} \mathrm{O}$, monoclinic & Atencio et al. (2008b) \\
\hline 50 & 2009-039 & Manganoeudialyte & $\mathrm{Na}_{14} \mathrm{Ca}_{6} \mathrm{Mn}_{3} \mathrm{Zr}_{3}\left[\mathrm{Si}_{26} \mathrm{O}_{72}(\mathrm{OH})_{2}\right] \mathrm{Cl}_{2} \cdot 4 \mathrm{H}_{2} \mathrm{O}$, trigonal & Nomura et al. (2010) \\
\hline 51 & 2009-076 & Qingheiite- $\left(\mathrm{Fe}^{2+}\right)$ & $\mathrm{Na}_{2} \mathrm{Fe}^{2+} \mathrm{MgAl}\left(\mathrm{PO}_{4}\right)_{3}$, monoclinic & Hatert et al. (2010) \\
\hline 52 & & Hydroxycalcioromeite & $\mathrm{Ca}_{1.5} \mathrm{Sb}_{2}^{5+} \mathrm{O}_{6}(\mathrm{OH})$, cubic & Atencio et al. (2010) \\
\hline 53 & $2010-047$ & Carlosbarbosaite & $\left(\mathrm{UO}_{2}\right)_{2} \mathrm{Nb}_{2} \mathrm{O}_{6}(\mathrm{OH})_{2} \cdot 2 \mathrm{H}_{2} \mathrm{O}$, orthorhombic & Atencio et al. (2012) \\
\hline 54 & $2010-078$ & Jacutingaite & $\mathrm{Pt}_{2} \mathrm{HgSe}_{3}$, trigonal & Vymazalová et al. (2012) \\
\hline 55 & 2011-071 & Fluor-elbaite & $\mathrm{Na}\left(\mathrm{Li}_{1.5} \mathrm{Al}_{1.5}\right) \mathrm{Al}_{6}\left(\mathrm{Si}_{6} \mathrm{O}_{18}\right)\left(\mathrm{BO}_{3}\right)_{3}(\mathrm{OH})_{3} \mathrm{~F}$, trigonal & Bosi et al. (2013) \\
\hline 56 & 2011-103 & Hydrokenomicrolite & $\square_{2} \mathrm{Ta}_{2}\left[\mathrm{O}_{4}(\mathrm{OH})_{2}\right]\left(\mathrm{H}_{2} \mathrm{O}\right)$, cubic & Andrade et al. (2013a) \\
\hline 57 & $2012-036$ & Fluorcalciomicrolite & $\mathrm{Ca}_{1.5} \mathrm{Ta}_{2} \mathrm{O}_{6} \mathrm{~F}$, cubic & Andrade et al. (2013b) \\
\hline 58 & 2012-090 & Pauloabibite & $\mathrm{NaNbO}_{3}$, trigonal & Menezes Filho et al. (2015) \\
\hline 59 & 2012-099 & Césarferreiraite & $\mathrm{Fe}^{2+} \mathrm{Fe}_{2}^{3+}\left(\mathrm{AsO}_{4}\right)_{2}(\mathrm{OH})_{2} \cdot 8 \mathrm{H}_{2} \mathrm{O}$, triclinic & Scholz et al. (2014) \\
\hline 60 & 2013-007 & Correianevesite & $\mathrm{Fe}^{2+} \mathrm{Mn}_{2}^{2+}\left(\mathrm{PO}_{4}\right)_{2} \cdot 3 \mathrm{H}_{2} \mathrm{O}$, orthorhombic & Chukanov et al. (2014) \\
\hline 61 & 2013-020 & Almeidaite & $\mathrm{PbZn}_{2}(\mathrm{Mn}, \mathrm{Y})\left(\mathrm{Ti}, \mathrm{Fe}^{3+}\right)_{18} \mathrm{O}_{37}(\mathrm{OH}, \mathrm{O})$, trigonal & Menezes Filho et al. (2013) \\
\hline 62 & $2013-073$ & Hydroxycalciomicrolite & $\mathrm{Ca}_{1.5} \mathrm{Ta}_{2} \mathrm{O}_{6}(\mathrm{OH})$, cubic & Andrade et al. (2013c) \\
\hline 63 & 2013-102 & Fluorlamprophyllite & $\mathrm{Na}_{3}(\mathrm{SrNa}) \mathrm{Ti}_{3}\left(\mathrm{Si}_{2} \mathrm{O}_{7}\right)_{2} \mathrm{O}_{2} \mathrm{~F}_{2}$, monoclinic & Andrade et al. (2014) \\
\hline 64 & 2013-108 & Waimirite-(Y) & $\mathrm{YF}_{3}$, orthorhombic & Atencio et al. (2015) \\
\hline 65 & 2014-075 & Lefontite & $\mathrm{Fe}_{2} \mathrm{Al}_{2} \mathrm{Be}\left(\mathrm{PO}_{4}\right)_{2}(\mathrm{OH})_{6}$, orthorhombic & Yang et al. (2015) \\
\hline
\end{tabular}




\section{Main authors of mineralogical studies}

From the table, it is clear that two researchers were very productive in the past with respect to Brazilian new minerals (Hussak and Lindberg), and two other (Menezes Filho and Andrade) contributed more recently.

Franz Eugen Hussak (1856-1911) of Graz, Austria, studied under Ferdinand Zirkel in Leipzig, where he earned his $\mathrm{PhD}$. He was a member of the Geological Survey of Brazil (Geographic and Geologic Commission) in São Paulo from 1887 to 1895 and wrote numerous articles on Brazilian mineralogy, including six new species descriptions: zirkelite, derbylite, tripuhyite, senaite, florencite-(Ce) and gorceixite. Hussak also introduced some invalid mineral names: Palladiumplatin, chalmersite, lewisite, brazilite, harttite and camposite. He was honored with the mineral "hussakite", discredited by the proper Hussak (1907). Xenotime-(Y), $\mathrm{Y}\left(\mathrm{PO}_{4}\right)$ tetragonal, was identified by Gorceix (1885) in diamondiferous sands of Datas, Minas Gerais. Kraus and Reitinger (1901) found about $6 \mathrm{wt} . \% \mathrm{SO}_{3}$ and gave the name hussakite to the mineral, a "sulfate-phosphate of Y, Er, and small percentage of Gd". Subsequent analyses of identical material by Hussak (1907) did not confirm the presence of $\mathrm{SO}_{3}$ in sufficient amounts $(0.25 \mathrm{wt} . \%$ at the most) for a new species to be designated. In addition, Hussak (1907) determined that the rock-forming mineral identified as hussakite by Rösler (1902) is zircon, not xenotime-(Y).

Marie Louise Lindberg (-Smith) (1918-2005), from the United States Geological Survey (USGS), described five new Brazilian mineral species from the Sapucaia quarry, Galileia, Minas Gerais (frondelite, faheyite, moraesite, barbosalite and tavorite), the problematic lipscombite and the discredited avelinoite. The mineral lindbergite was named in her honour (Atencio et al. 2004b).

Luiz Alberto Dias Menezes Filho (1950-2014), mining engineer, mineral collector and merchant, was born in São Paulo, Brazil. His first job was with Serrana S.A. de Mineração, operator of the Jacupiranga mine in Cajati, São Paulo, where he worked as mine engineer in the mining and crushing operations, and as process engineer in the apatite flotation plant. In recent years, Luiz was working on a PhD in Economic Geology at the Universidade Federal de Minas Gerais. $\mathrm{He}$ is the first author of pauloabibite and almeidaite, and a coauthor of ruifrancoite, lindbergite, carlosbarbosaite, guimarãesite, correianevesite, bendadaite and césarferreiraite. He also collected the samples used for the first official description of lanthanite-(Nd), quintinite and fluornatromicrolite. Menezesite, the first natural heteropolyniobate, honors Luiz Menezes (Atencio et al. 2008a).
Marcelo Barbosa de Andrade (born 1973) is the first author of fluorlamprophyllite, hydrokenomicrolite, fluorcalciomicrolite and hydroxycalciomicrolite. He is a coauthor of pauloabibite and waimirite-(Y). Marcelo is responsible for establishing the Center of characterization of new mineral species in the Instituto de Física de São Carlos (IFSC), Universidade de São Paulo (USP), São Carlos, São Paulo.

\section{GEMOLOGICAL MINERALS}

The two first type species from Brazil, discovered in the $18^{\text {th }}$ century, chrysoberyl and euclase, are important gemological minerals. Coincidently, both are Be-Al minerals, the first an oxide, and the second a silicate. Two other gem minerals, tourmaline-supergroup members, were published only in the $21^{\text {st }}$ century: uvite and fluor-elbaite.

According to Leonardos (1970), it is probable that the chrysoberyl analyzed by Klaproth (1795) [alumina 71, silica 18, lime 6, oxide of iron 1.5, loss 3, total 99.5 wt.\%] was from Brazil. In fact, chrysoberyl is $\mathrm{BeAl}_{2} \mathrm{O}_{4}$, but at that time beryllium had not been isolated. The gem known in Brazil as chrysolite, and classified by Werner (Hoffmann 1789; Karsten 1789) as chrysoberyl (Krisoberil), had been known since the middle of the $18^{\text {th }}$ century from alluvium in northern Minas Gerais [especially in the area of Araçuaí, old Calhau, Minas Gerais (Leonardos 1945)], associated with colorless and blue topaz, aquamarine, tourmaline and garnet. The name chrysolite was used by Romé de l'Isle (1772) for the gem variety of olivine, but, apparently, both de l'Isle and Werner confused the gem names of antiquity. Chrysolite or "gold stone" of Pliny probably was topaz, and chrysoberyl of antiquity, as the name indicates, was golden beryl. Klaproth (1795) simply designated chrysoberyl as Alaunerde + Kieselerde (alumina + silica). Haüy (1798) gave it the name cymophane. Nevertheless, the name chrysoberyl prevailed, and Seybert (1824) obtained a correct analysis showing it to be a beryllium mineral.

It is probable that the first specimens of euclase taken to Europe by Dombey, in 1785, came from Ouro Preto, Minas Gerais, and not from Peru, where it is not known to occur (Leonardos 1970). According to Dana (1892), the name was given by Haüy who stated that his name, euclase, was published by Daubenton in an early edition of his Tableaux méthodiques des Minéraux (the first edition is dated 1784). After publishing the name and description, without crediting Haüy (Delamétherie 1792), Delamétherie then gives Haüy full credit (Delamétherie 1797). Eschwege (1822) recognised the provenance of the mineral when he identified it in a topaz lot originating from Ouro Preto. A revision of 
the occurrence of this mineral in Brazil was made by Chaves and Karfunkel (1994).

Uvite, originally defined by Kunitz (1929), was considered to have an ideal formula $\mathrm{CaMg}_{3}\left(\mathrm{Al}_{5} \mathrm{Mg}\right)\left(\mathrm{Si}_{6} \mathrm{O}_{18}\right)$ $\left(\mathrm{BO}_{3}\right)_{3}(\mathrm{OH})_{4}$. This formula was based on the examination of tourmalines from Uva (Sri Lanka), De Kalb (New York) and Gouverneur (New York) with OH contents of approximately 4 apfu. However, all other analyses from these localities contain F in the 0.5 - 1.0 apfu range. Dunn et al. (1977) designated a sample of uvite from Uva, Sri Lanka as a neotype, and this sample has an anion content of $\left(\mathrm{OH}_{2.90} \mathrm{~F}_{0.76} \mathrm{O}_{0.34}\right)$. This anion content would mandate that the $W$ site would be dominated by $\mathrm{F}$ and that the type uvite should most properly be termed fluor-uvite. More recently, uvitic species with $\mathrm{OH}$ dominant on the $W$ site was described by Clark et al. (2010) from the Brumado mine, Bahia. Complete data were not yet published.

A previous study on the crystal chemistry of the tourmaline-supergroup minerals (Federico et al. 1998) demonstrated the presence of the "fluor-" equivalent of elbaite in the Cruzeiro mine (São José da Safira, Minas Gerais, Brazil). Moreover, the fluor-elbaite end-member was predicted by Hawthorne and Henry (1999) with the ideal formula $\mathrm{Na}\left(\mathrm{Li}_{1.5} \mathrm{Al}_{1.5}\right) \mathrm{Al}_{6} \mathrm{Si}_{6} \mathrm{O}_{18}\left(\mathrm{BO}_{3}\right)_{3}(\mathrm{OH})_{3} \mathrm{~F}$, derived from the root composition of elbaite via the substitution $\mathrm{F} \rightarrow \mathrm{OH}$ at the $\mathrm{W}$ position. The mineral is also found in the Urubu mine (Itinga, Minas Gerais) (Bosi et al. 2013).

\section{A SELECTION OF BRAZILIAN TYPE MINERALS}

Plates 1 to 4 show a series of Brazilian new minerals described in this century. Atencioite (Fig 1B, photo: Thales Trigo) occurs as brownish spherules on quartz and albite, from João Firmino claim, Linópolis, Divino das Laranjeiras, Minas Gerais. The major spherule has approximately $8 \mathrm{~mm}$ in diameter. Ruifrancoite (Fig. 4C, photo: Thales Trigo) displays orange brown botryoidal arrangements, on muscovite, in close association with cyrilovite and meurigite, from Sapucaia (Proberil) mine, Sapucaia do Norte, Galileia, Minas Gerais. Guimarãesite (Fig. 2D) forms peripheral zones in crystals of roscherite-group minerals. The inner zones of the crystals are $\mathrm{Mg}$-rich (and correspond to zanazziite) or Fe-rich (greifensteinite and/or ruifrancoite) from a granite pegmatite near the Piauí river, Itinga, Minas Gerais.

Hydrokenomicrolite (Fig. 3A) forms an octahedron-dodecahedron crystal, from Volta Grande pegmatite, Nazareno, Minas Gerais. Hydroxycalciomicrolite (Fig. 3B) is an octahedron-dodecahedron crystal, from Volta Grande pegmatite, Nazareno, Minas Gerais. Almeidaite (Fig. 1A) is an isolated, black, opaque, sub-metallic, platy crystal flattened on [0001] (23 x $22 \times 6 \mathrm{~mm})$, from Novo Horizonte, Bahia. Carlosbarbosaite (Fig. 2A) forms crystals elongated along [001] and flattened on (100), from Jaguaraçu pegmatite, Jaguaraçu, Minas Gerais. Manganoeudialyte (Fig. 3D) forms anhedral crystals, from Pedra Balão, Poços de Caldas, Minas Gerais.

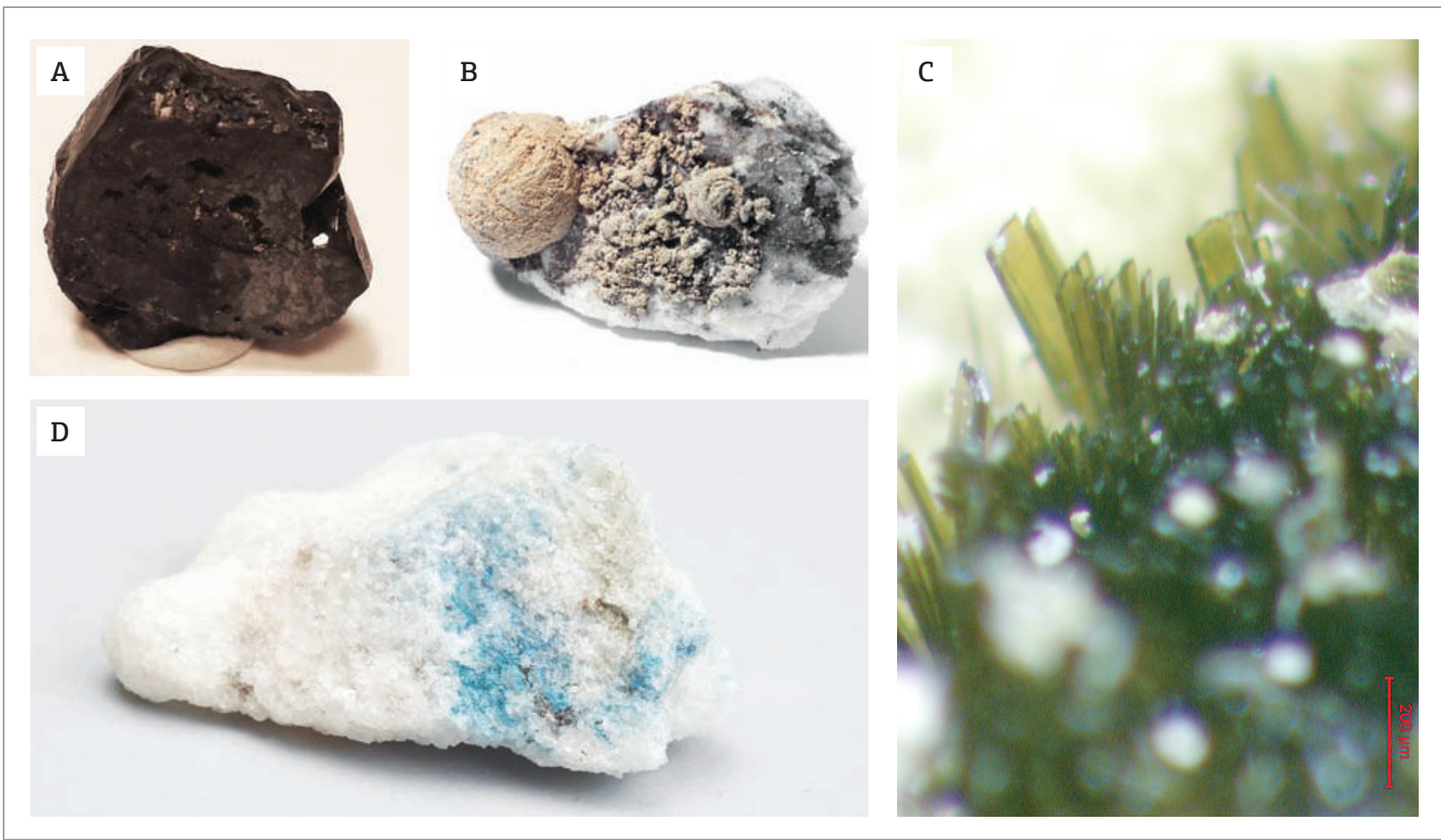

Plate 1. (A) Almeidaite; (B) Atencioite; (C) Bendadaite; (D) Brumadoite. 
Bendadaite (Fig. 1C) displays elongated tabular dark greenish-brown crystals, from Almerindo quarry, Linópolis, Divino das Laranjeiras, Minas Gerais. Césarferreiraite (Fig. 2B, field of view: $1 \mathrm{~cm}$ ) forms pale yellow tabular aggregates, in miarolitic cavity in albite, with pharmacosiderite, scorodite and arsenopyrite from Eduardo mine, Conselheiro Pena, Minas Gerais. Brumadoite (Fig. 1D, photo: Thales Trigo) occurs as pale blue microcrystalline aggregates on magnesite, from Pedra Preta mine, Serra das Éguas, Brumado, Bahia. The longest dimension of the specimen is $6.5 \mathrm{~cm}$. Menezesite (Fig. 4A, photo: Tatiana Dias Menezes) display $-0.5 \mathrm{~mm}$ reddish brown rhombododecahedra crystals, on dolomite, from Jacupiranga mine, Cajati, São Paulo.

Coutinhoite (Fig. 2C, photo: Thales Trigo) is an irregular aggregate with very small flaky crystals, from Córrego do Urucum mine, Galileia, Minas Gerais. Lindbergite (Fig. 3C) forms interlocked irregularly contoured platelets, from Boca Rica mine, Sapucaia do Norte, Galileia, Minas Gerais. Pauloabibite (Fig. 4C, field of view: $4 \mathrm{~mm}$ ) occurs as encrustations of pinkish brown platy crystals in dolomite, from Jacupiranga mine, Cajati, São Paulo. Waimirite-(Y) (Fig. 4D) forms platy crystals, with halloysite, from Pitinga mine, Presidente Figueiredo, Amazonas.

\section{TECHNOLOGICALLY IMPORTANT MINERALS}

Some type minerals from Brazil are very important technologically speaking. Some examples may be mentioned. All these minerals occur in very small amount, which does not allow its extraction, but they can serve as a model for obtaining the synthetic analogue on an industrial scale.

Menezesite (Atencio et al. 2008a; Fig. 4A) is the first natural heteropolyniobate. The second natural heteropolyniobate, aspedamite, isostructural with menezesite, was described in Southern Norway, by Cooper et al. (2012). The first synthetic heteropolyniobates were obtained by Nyman et al. (2002, 2004). Heteropolyanions are negatively charged clusters of corner- and edge-sharing early transition-metal $\mathrm{MO}_{6}$ octahedra and heteroatom usually located in the interior of the cluster. The geometry, composition
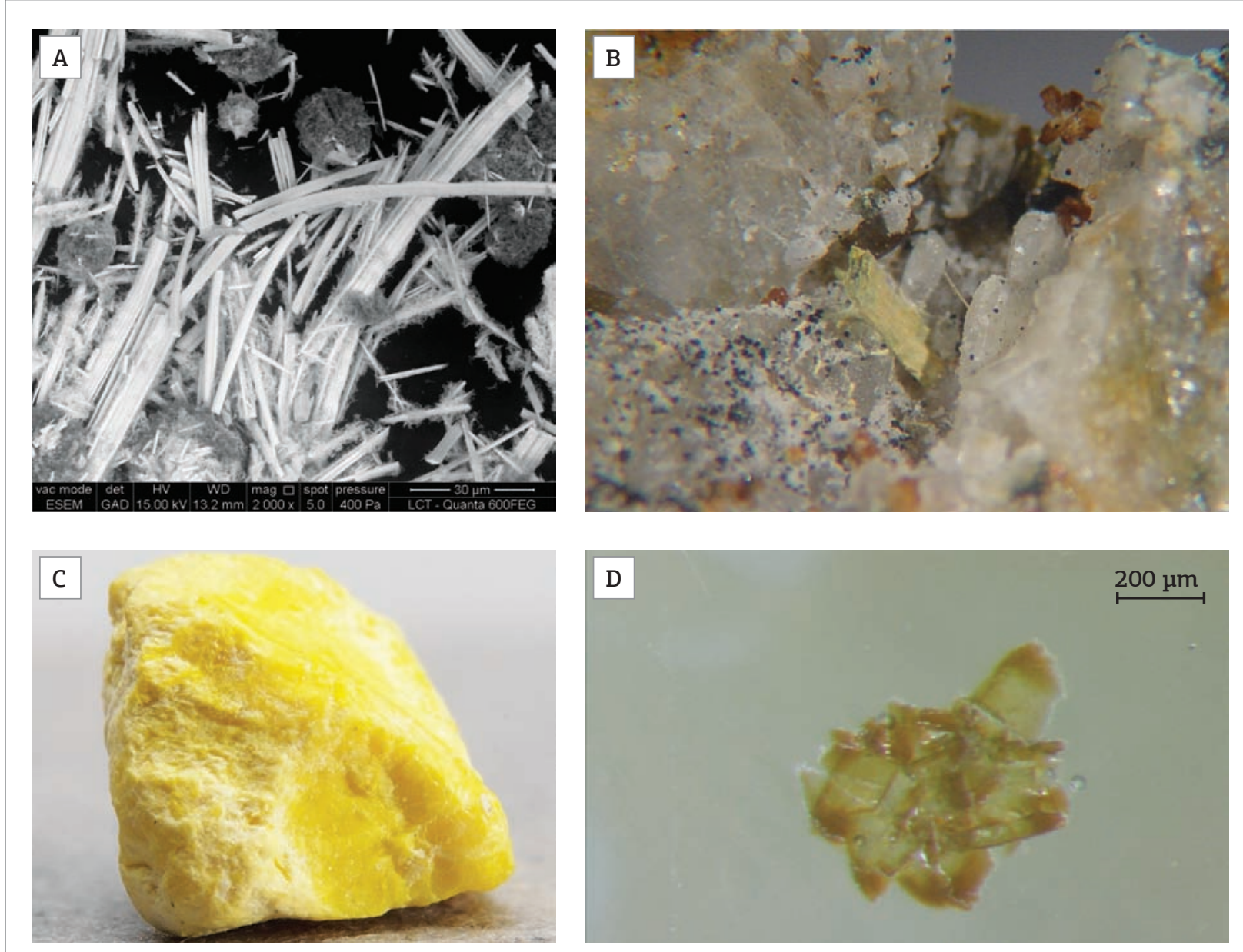

Plate 2. (A) Carlosbarbosaite; (B) Césarferreiraite; (C) Coutinhoite; (D) Guimarãesite. 


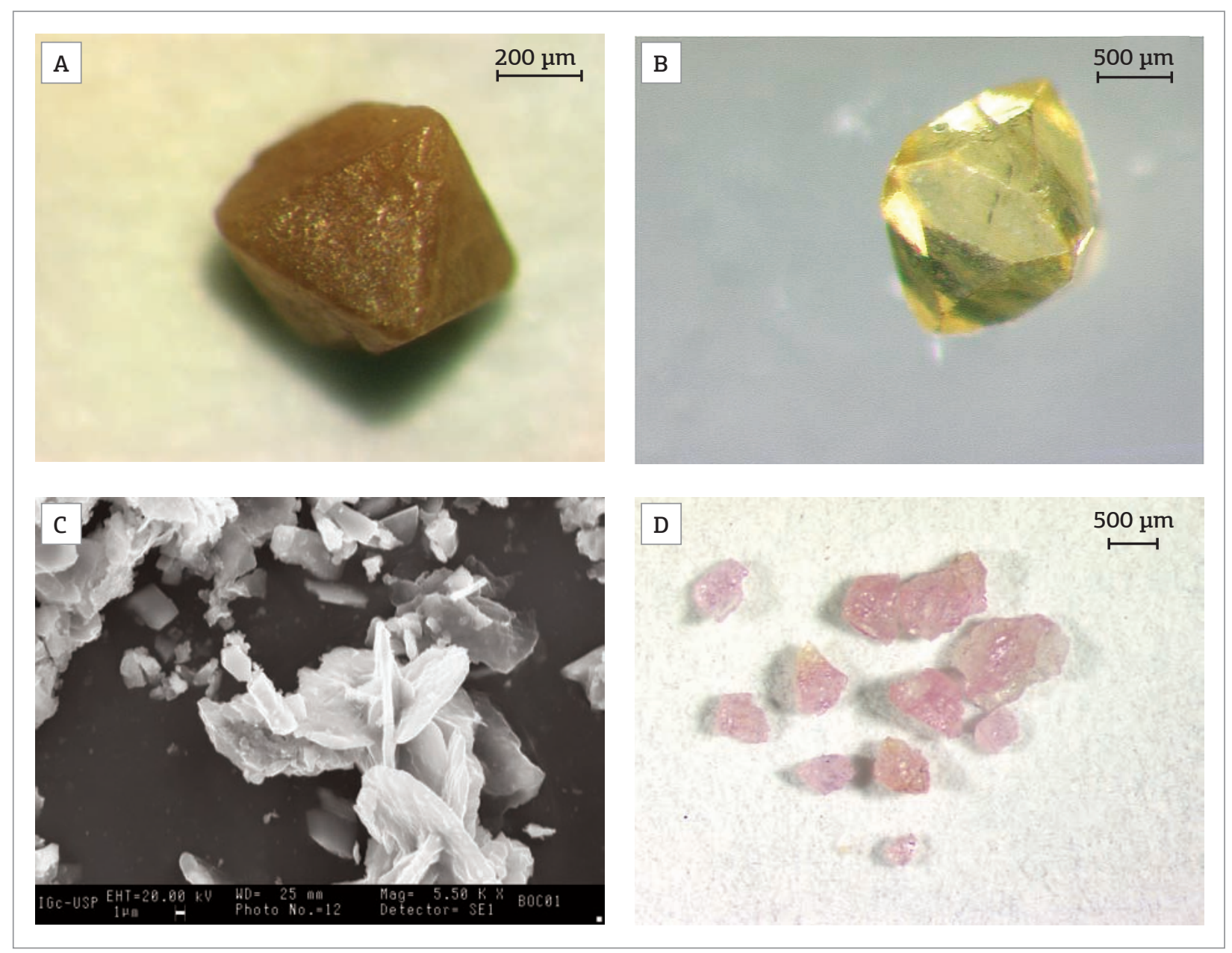

Plate 3. (A) Hydrokenomicrolite; (B) Hydroxycalciomicrolite; (C) Lindbergite; (D) Manganoeudialyte.

and charge of these clusters are varied through synthesis parameters, and cluster properties are highly tunable as a function of these characteristics. Heteropolyanions have been employed in a range of applications that include virus-binding inorganic drugs (including AIDs virus), homogeneous and heterogeneous catalysts, electro-optic and electrochromic materials, metal and protein binding, and as building blocks for nanostructuring of materials. The heteropolyanions of W, Mo and V, which have found numerous applications, are formed simply by acidification of solutions of their oxoanions. Under similar conditions, these oxoanion precursors are not available for $\mathrm{Nb}$, and $\mathrm{Nb}$-oxo chemistry is dominated by formation of the Lindquist ion $\left[\mathrm{Nb}_{6} \mathrm{O}_{19}\right]^{8-}$ only. However, heteropolyniobate formation is favored in hydrothermal reactions of aqueous, alkaline precursor mixtures. Unlike other heteropolyanions, heteropolyniobates are basic rather than acidic, which means they can survive longer and possibly even thrive in the generally basic or neutral environments of radioactive wastes and blood, respectively. Once such compounds bind with a virus, it is no longer capable of entering a cell to damage it. Heteropolyanions may also bind with radionuclides (actinides), which remove them from the mixture by phase separation for easier and safer storage. Menezesite has been found in the last years of the decade of 1970 by Luiz Alberto Dias Menezes Filho (see above), but its study has begun only in May 2003.

Coutinhoite (Atencio et al. 2004a, Fig. 2C) is a thorium uranyl silicate probably isostructural with weeksite. The weeksite structure would be then an important depository of $\mathrm{Th}^{4+}$. The importance of uranium mineralogy to understand the genesis of uranium deposits, as well as for environmental applications, was emphasized by Jackson and Burns (2001). Uranyl compounds that may form by the alteration of nuclear waste will incorporate radionuclides into their structures, thereby retarding their release. Uranyl silicates (e.g., uranophane, uranophane-beta, boltwoodite, haiweeite, weeksite) are likely to be abundant in a geological repository for nuclear waste, owing to the alteration of spent nuclear fuel and borosilicate waste glass in the presence of 


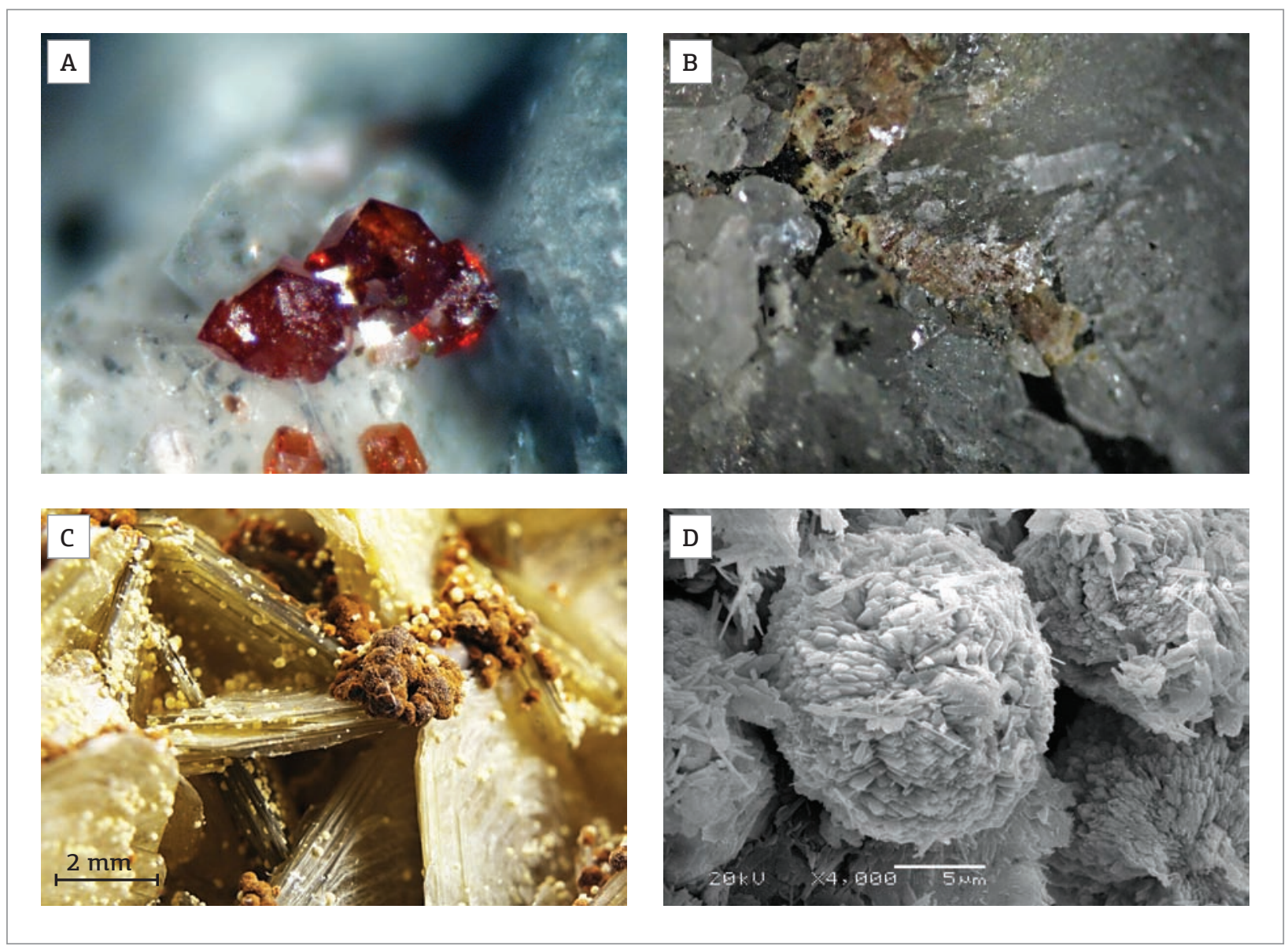

Plate 4. (A) Menezesite; (B) Pauloabibite; (C) Ruifrancoite; (D) Waimirite-(Y).

silicon derived from repository host-rocks. Thus, an understanding of the structures of uranyl silicates may be a key to understanding the long-term performance of a geological repository for nuclear waste. The name coutinhoite honors Professor José Moacyr Vianna Coutinho (born 1924) of the Instituto de Geociências da Universidade de São Paulo.

Lindbergite (Atencio et al. 2004b; Fig. 3C) is an oxalate found for the first time in 2002, in the Lavra da Boca Rica, Sapucaia do Norte, Galileia Co., Minas Gerais, by Luiz Alberto Dias Menezes Filho. The mineral has been named in honor of Marie Louise Lindberg (-Smith) (see above), from the USGS, who described several new mineral species from the nearby Lavra Sapucaia. Lindbergite is a secondary mineral in the granite pegmatite. The study of soluble oxalates is related to their use as precursors in the synthesis of high temperature superconductive ceramic materials, in the preparation of nanomaterials, and a number of other new materials due to the fact that the precipitation processes provide the possibility of controlling the chemical and physical properties of the final products. Oxalate systems are traditionally used for the separation and concentration of elements, especially rare earth and transuranian elements
(Donkova et al. 2004). In addition, the use of the synthetic equivalent of lindbergite in the process of photographic revelation and as a standard for chemical analysis was studied, respectively, by Huizing et al. (1977) and Coltman (1924).

Pauloabibite is trigonal $\mathrm{NaNbO}_{3}$ (Menezes Filho et al. 2015; Fig. 4B). $\mathrm{NaNbO}_{3}$ is well-known to exhibit a rich polymorphism based on the perovskite structure, with a number of displacive transition occurring over a range of temperatures, which may also be sensitive to both pressure and crystallite size. Doped forms of the material are currently the focus of much attention because of their piezoelectric properties (Modeshia et al. 2009). Much work has been carried out on the synthesis of alkaline niobates because of their excellent nonlinear optical, ferroelectric, piezoelectric, electro-optic, ionic conductive, pyroelectric, photorefractive, selective ion exchange and photocatalytic properties. For example, lead-free potassium and sodium niobates are potential substitutes for lead zirconium titanate as high-performance piezoelectric ceramics. The high lead content in piezoelectric PZT introduces serious concerns about environment pollution during the fabrication, use and disposal of the materials, and therefore increasing attention has been 
paid to environmental issues nowadays, so research on potential substitutes is urgent (Wu et al. 2010). The name honors Professor Paulo Abib Andery (1922-1976).

Waimirite-(Y) (Atencio et al. 2015; Fig. 4D) is orthorhombic $\mathrm{YF}_{3}$. Fluoride crystalline materials are commonly studied owing to their applications in solid state lasers and scintillators. Indeed, their good optical properties beside their low non-radioactive emissions (mainly because of the low cut-off phonon frequencies) make these materials good host matrices for visible or infrared light emission and other optical applications. It is well known that fluoride materials can be used as active media for tunable solid state lasers (Lage et al. 2004). The orthorhombic $\mathrm{YF}_{3}$ crystals are non-hygroscopic and colourless under normal conditions essential for use as active laser materials. Kollia et al. (1995) showed that $\mathrm{YF}_{3}$ could be a laser material.

\section{PROBLEMATIC BRAZILIAN MINERALS}

The IMA-CNMNC list includes two questionable minerals with Brazil as the type locality: joséite-A and palladinite. In addition, arrojadite-(KFe), lipscombite and tantalaeschynite-(Y) are erroneously considered as Brazilian type minerals, and lanthanite-(La) is, also erroneously, not considered as a type specimen of Brazil.

The name joséite was introduced by Kenngott (1853) for a mineral that occurs in veins in limestone, associated with gold, at São José mine, near Mariana, Minas Gerais. Thompson (1949) named $\mathrm{Bi}_{4+\mathrm{x}} \mathrm{Te}_{1-\mathrm{x}} \mathrm{S}_{2}$ as joséite-A and $\mathrm{Bi}_{4+\mathrm{x}} \mathrm{Te}_{2-\mathrm{x}} \mathrm{S}$ as joséite- $\mathrm{B}$. The only two analyses of joséite from São José mine refer to the composition of joséite-B.

The name palladinite was introduced for a $\mathrm{PdO}$ compound, from Gongo Soco, Barão de Cocais, Minas Gerais (Shepard 1857). A complete mineralogical description of palladinite is still lacking in the literature, although Jedwab and Cassedanne (1998) note that this mineral "is in process of revalidation".

The IMA-CNMNC list gives arrojadite-( $\mathrm{KFe})$ as a type mineral from Brazil. Arrojadite was described as a new mineral species by Guimarães (1924) on a sample from the Alto Serra Branca pegmatite, Pedra Lavrada, Paraíba. According to Moore and Ito (1979), the "supposed arrojadite" from Serra Branca appears to be so highly altered as to constitute a probable mixture or possibly some other species. The name arrojadite today refers to a mineral group. According to the new nomenclature system (Chopin et al. 2006), in the absence of a more reliable analysis than the original one, the material from Paraíba cannot be specified further than arrojadite-(K), even if the pegmatitic occurrence makes an arrojadite-(KFe) $-(\mathrm{KNa})$ $\mathrm{Fe}^{2+}\left(\mathrm{CaNa}_{2}\right) \mathrm{Fe}^{2+}{ }_{13} \mathrm{Al}\left(\mathrm{PO}_{4}\right)_{11}\left(\mathrm{PO}_{3} \mathrm{OH}\right)(\mathrm{OH})_{2}$ - composition likely. Nevertheless, the empirical formula is very different from the formula of arrojadite-(KFe) and the other arrojadite-group minerals.

Lipscombite is another mineral quoted as a type mineral from Brazil. The name lipscombite was first used by Gheith (1953) for synthetic compounds with compositions ranging from $\mathrm{Fe}^{2+}{ }_{8}\left(\mathrm{PO}_{4}\right)_{4}(\mathrm{OH})_{4}$ to $\mathrm{Fe}^{3+}{ }_{5.3}\left(\mathrm{PO}_{4}\right)_{4}(\mathrm{OH})_{4}$. Lindberg and Pecora (1958) published an abstract on a mineral from the Sapucaia mine, Galileia, Minas Gerais, occurring as a secondary alteration product in a pegmatite, associated with several other phosphates. They referred to this mineral as "manganoan lipscombite" with the formula $\left(\mathrm{Mn}^{2+}, \mathrm{Fe}^{2+}\right) \mathrm{Fe}_{2}^{3+}\left(\mathrm{PO}_{4}\right)_{2}(\mathrm{OH})_{2}$. Čech et al. (1961) described the "first natural occurrence of lipscombite", with the formula $\mathrm{Fe}^{2+} \mathrm{Fe}_{2}^{3+}\left(\mathrm{PO}_{4}\right)_{2}(\mathrm{OH})_{2}$, from Otov, near Domazlice, Bohemia, Czech Republic. Lindberg (1962) published the complete description of "manganoan lipscombite", this time with the formula $\left(\mathrm{Fe}^{2+}, \mathrm{Mn}^{2+}\right) \mathrm{Fe}_{2}^{3+}\left(\mathrm{PO}_{4}\right)_{2}(\mathrm{OH})_{2}$, and suggested that the type locality for lipscombite should be Galileia, Minas Gerais. The "manganoan lipscombite", described by Lindberg (1962) seems to be a different species when compared with that of Čech et al. (1961), with Mn or $\mathrm{Fe}^{3+}$ predominant over $\mathrm{Fe}^{2+}$ in the A-site. The $\mathrm{X}$-ray powder diffraction data is virtually identical, but the chemical results for the Brazilian sample are very poor and insufficient to derive a good empirical formula. Based on these considerations, the Czech Republic should be the type locality for lipscombite. The Brazilian mineral needs to be restudied, because it seems to be a new species.

Tantalaeschynite-(Y) was described by Adusumilli et al. (1974) in the Raposa pegmatite, São José do Sabugi, Paraíba, as a metamict mineral. It was appreved by IMA (1969-043) and is in the CNMNC - IMA list as a type mineral from Brazil. When heated, it gave an $\mathrm{X}$-ray diffraction pattern similar to that of aeschynite. The formula $\left[\mathrm{Ca}_{0.47}(\mathrm{Y}, \mathrm{Ln})_{0.425}(\mathrm{Th}, \mathrm{U})_{0.11}\right]$ $\left(\mathrm{Ta}_{0.75} \mathrm{Ti}_{0.62} \mathrm{Nb}_{0.595} \mathrm{Fe}_{0.05}\right) \mathrm{O}_{6}$ was derived from electron microprobe analyses. The formula, recalculated from the original data, resulted in: $\left(\mathrm{Ca}_{0.505} \mathrm{Y}_{0.186} \mathrm{Th}_{0.112} \mathrm{Ce}_{0.103} \mathrm{Nd}_{0.051} \mathrm{La}_{0.036} \mathrm{Yb}_{0.016}\right.$ $\left.\operatorname{Pr}_{0.016} \mathrm{Sm}_{0.015} \mathrm{Gd}_{0.015} \mathrm{Dy}_{0.010} \mathrm{Er}_{0.009} \mathrm{U}_{0.007}\right)_{\Sigma 1.081}\left(\mathrm{Ta}_{0.812} \mathrm{Nb}_{0.731}\right.$ $\left.\mathrm{Ti}_{0.669} \mathrm{Fe}_{0.051}\right)_{52.263} \mathrm{O}_{6}$ with the simplified formula $(\mathrm{Ca}, \mathrm{Y})$ $(\mathrm{Ta}, \mathrm{Nb}, \mathrm{Ti})_{2} \mathrm{O}_{6}$. The sum $\mathrm{Y}+\mathrm{REE}=0.457$, and $\mathrm{Ca}=0.505$, so, following the CNMMN - IMA rules of nomenclature (Nickel and Grice 1998), it should not be considered as a rare earth elements (REE)-mineral. A REE-mineral has REE $+\mathrm{Y}+\mathrm{Sc}>\mathrm{Ca}$ (in atomic numbers), thus, the suffix $-(\mathrm{Y})$ is incorrect. Rynersonite was described by Foord and Mrose (1978) as $\mathrm{Ca}(\mathrm{Ta}, \mathrm{Nb})_{2} \mathrm{O}_{6}$ and tantalaeschynite-(Y) could be considered as a metamict variety of yttrian rynersonite but a new study of the type tantalaeschynite-(Y) specimen is needed to check its chemical composition. 
The type locality of lanthanite-(La) appears in the IMACNMNC list as Sweden, but should be changed to Brazil. Lanthanite was first described from Bastnäs, Sweden (Berzelius 1825). The formula $(\mathrm{La}, \mathrm{Ce})_{2}\left(\mathrm{CO}_{3}\right)_{3} \cdot 8 \mathrm{H}_{2} \mathrm{O}$ was attributed following a more complete chemical analysis of the mineral from Bastnäs by Lindström (1910) (wt.\%): (La,Di) ${ }_{2} \mathrm{O}_{3}$ 28.34, $\mathrm{Ce}_{2} \mathrm{O}_{3} 25.52, \mathrm{Y}_{2} \mathrm{O}_{3} 0.79, \mathrm{CO}_{2} 21.95, \mathrm{Ce}_{2} \mathrm{O}_{3} 25.52$, $\mathrm{H}_{2} \mathrm{O} 23.40$, total 100.13. Di represents 'didymium', a name applied to several rare earth elements, including $\mathrm{Nd}, \mathrm{Pr}$, etc., which could not be chemically differentiated at that time; accordingly the value of $28.34 \mathrm{wt}$ \% represents not only $\mathrm{La}_{2} \mathrm{O}_{3}$ but also $\mathrm{Di}_{2} \mathrm{O}_{3}$. The true percentage of $\mathrm{La}_{2} \mathrm{O}_{3}$ could therefore be lower than that of $\mathrm{Ce}_{2} \mathrm{O}_{3}$ in the analysis, and, if so, the predominant REE would be Ce (or $\mathrm{Nd}$ ) and not La. Current rules of nomenclature for rare earth minerals (Bayliss \& Levinson 1988) state that the mineral name be suffixed with the predominant member of the REE group. Atencio et al. (1989) confirmed the species to be lanthanite-(Ce). Therefore, the type locality for lanthanite-(La) currently accepted as Bastnäs, Sweden, is not appropriate. The first published analyses for lanthanite-(La) were given on the ICDD card 30-678 for a mineral from Curitiba, Paraná.

\section{ACKNOWLEDGEMENTS}

Thanks are due to the referee Rainer A. Schultz-Güttler and to the editor Umberto G. Cordani for helpful comments and suggestions.

\section{REFERENCES}

Adusumilli M.S., Kieft C., Burke E.A.J. 1974. Tantal-aeschynite, a new mineral of the aeschynite group from the Borborema Region, northeastern Brazil. Mineralogical Magazine, 39:571-576.

Andrade M.B., Atencio D., Chukanov N.V., Ellena, J. 2013a. Hydrokenomicrolite, $\left(\square, \mathrm{H}_{2} \mathrm{O}\right)_{2} \mathrm{Ta}_{2}(\mathrm{O}, \mathrm{OH})_{6}\left(\mathrm{H}_{2} \mathrm{O}\right)$, a new microlitegroup mineral from Volta Grande pegmatite, Nazareno, Minas Gerais, Brazil. American Mineralogist, 98:292-296.

Andrade M.B., Atencio D., Persiano A.I.C., Ellena J. 2013b. Fluorcalciomicrolite, $(\mathrm{Ca}, \mathrm{Na}, \square)_{2} \mathrm{Ta}_{2} \mathrm{O}_{6} \mathrm{~F}$, a new microlite-group mineral from Volta Grande pegmatite, Nazareno, Minas Gerais, Brazil. Mineralogical Magazine, 77:2989-2996

Andrade M.B., Yang H., Atencio D., Downs R.T., Chukanov N.V., Lemée-Cailleau M.-H., Persiano A.L.C., Goeta A.E., Ellena, J. 2013c. Hydroxycalciomicrolite, IMA 2013-073. CNMNC Newsletter n. 18, December 2013, p. 3252; Mineralogical Magazine, 77:3249-3258.

Andrade M.B., Yang H., Downs R.T., Färber G., Contreira Filho R.R., Evans, S.H., Loehn C.W., Schumer, B.N. 2014. Fluorlamprophyllite, IMA 2013-102. CNMNC Newsletter n. 19, February 2014, page 166; Mineralogical Magazine, 78:165-170.

Atencio D. 2000. Type Mineralogy of Brazil. Preliminary edition. São Paulo: Museu de Geociências - Universidade de São Paulo, 114 p.

Atencio D., Andrade M.B., Christy A.G., Giere R., Kartashov P.M. 2010. The pyrochlore supergroup of minerals: nomenclature. Canadian Mineralogist, 48:673-698.

Atencio D., Bastos Neto A.C., Pereira V.P., Ferron J.T.M.M., Hoshino M., Moriyama T., Watanabe Y., Miyawaki R., Coutinho J.M.V., Andrade M.B., Domanik K., Chukanov N.V., Momma K., Hirano H., Tsunematsu M. 2015. Waimirite-(Y), orthorhombic $\mathrm{YF}_{3}$, a new mineral from the Pitinga mine, Presidente Figueiredo, Amazonas, Brazil, and from Jabal Tawlah, Saudi Arabia: Description and crystal structure. Mineralogical Magazine, 79 (in press).

Atencio D., Bevins R.E., Fleischer M., Williams C.T., Williams P.A. 1989. Revision of the lanthanite group and new data for specimens from Bastnäs, Sweden, and Bethlehem, USA. Mineralogical Magazine, 53:639-642.
Atencio D., Carvalho F.M.S., Matioli P.A. 2004a. Coutinhoite, a new thorium uranyl silicate hydrate from Urucum mine, Galiléia, Minas Gerais, Brazil. American Mineralogist, 89:721-724.

Atencio D., Chukanov N.V., Coutinho J.M.V., Menezes Filho L.A.D., Dubinchuk V.T., Möckel S. 2007. Ruifrancoite, a new $\mathrm{Fe}^{3+}$-dominant monoclinic member of the roscherite group from Galiléia, Minas Gerais, Brazil. Canadian Mineralogist, 45:1263-1273

Atencio D., Coutinho J.M.V., Doriguetto A.C., Mascarenhas Y.P., Ellena J.A., Ferrari V.C. 2008a. Menezesite, the first natural heteropolyniobate, from Cajati, São Paulo, Brazil: Description and crystal structure. American Mineralogist, 93:81-87.

Atencio D., Coutinho J.M.V., Graeser S., Matioli P.A., Menezes Filho L.A.D. 2004b. Lindbergite, a new manganese oxalate dihydrate from Boca Rica mine, Galiléia, Minas Gerais, Brazil, and other occurrences. American Mineralogist, 89:1087-1091

Atencio D., Coutinho J.M.V., Mascarenhas Y.P., Ellena J.A. 2006. Matioliite, the Mg-analogue of burangaite, from Gentil mine, Mendes Pimentel, Minas Gerais, Brazil, and other occurrences. American Mineralogist, 91:1932-1936.

Atencio D., Roberts A.C., Cooper M.A., Menezes Filho L.A.D., Coutinho J.M.V., Stirling J.A.R., Ball N.A., Moffatt E., Chaves M.L.S.C., Brandão P.R.G., Romano A.W. 2012. Carlosbarbosaite, ideally $\left(\mathrm{UO}_{2}\right)_{2} \mathrm{Nb}_{2} \mathrm{O}_{6}(\mathrm{OH})_{2} \cdot 2 \mathrm{H}_{2} \mathrm{O}$, a new hydrated uranyl niobate mineral with tunnels from Jaguaraçu, Minas Gerais, Brazil: description and crystal structure. Mineralogical Magazine, 76:75-90.

Atencio D., Roberts A.C., Matioli P.A., Stirling J.A.R., Venance K., Doherty W.E., Stanley C.J., Rowe R., Carpenter G.J.C., Coutinho J.M.V. 2008b. Brumadoite, a new copper tellurate hydrate, from Brumado, Bahia, Brazil. Mineralogical Magazine, 72:1201-1205.

Bayliss P. \& Levinson A.A. 1988. A system of nomenclature for rare-earth mineral species: Revision and extension. American Mineralogist, 73:422-423.

Berzelius J. 1825. Ueber die Veränderungen in dem chemischen Mineral-Systeme, Kohlensaures Cereroxydul, Taschenbuch für die gesammte Mineralogie mit Hinsicht auf die neuesten Entdeckungen, 19:193-218 (Zeitschrift für Mineralogie, 2:209). 
Bosi F., Andreozzi G.B., Skogby H., Lussier A., Ball N.A., Hawthorne F.C. 2013. Fluor-elbaite, $\mathrm{Na}\left(\mathrm{Li}_{1.5} \mathrm{Al}_{1.5}\right) \mathrm{Al}_{6}\left(\mathrm{Si}_{6} \mathrm{O}_{18}\right)\left(\mathrm{BO}_{3}\right)_{3}(\mathrm{OH})_{3} \mathrm{~F}, \quad \mathrm{a}$ new mineral species of the tourmaline supergroup. American Mineralogist, 98:297-303

Botelho N.F., Moura M.A., Peterson R.C., Stanley C.J., Silva D.V.G. 2006. Kalungaite, PdAsSe, a new platinum-group mineral from the Buraco do Ouro gold mine, Cavalcante, Goiás State, Brazil. Mineralogical Magazine, 70:123-130.

Botelho N.F., Roger G., d'Yvoire F., Moëlo Y., Volfinger M. 1994. Yanomamite, In $\mathrm{AsO}_{4} \cdot 2 \mathrm{H}_{2} \mathrm{O}$, a new indium mineral from topazbearing greisen in the Goiás Tin Province, Brazil. European Journal of Mineralogy, 6:245-254.

Buchwald V.F. 1990. A new mineral, arupite, $\mathrm{Ni}_{3}\left(\mathrm{PO}_{4}\right)_{2} \cdot 8 \mathrm{H}_{2} \mathrm{O}$, the nickel analogue of vivianite. Neues Jahrbuch für Mineralogie, Monatsheft, 76-80

Burns P.C., Roberts A.C., Stirling J.A.R., Criddle A.J., Feinglos M.N. 2000. Dukeite, $\mathrm{Bi}_{24}{ }^{3+} \mathrm{Cr}_{8}{ }^{6+} \mathrm{O}_{57}(\mathrm{OH})_{6}\left(\mathrm{H}_{2} \mathrm{O}\right)_{3}$, a new mineral from Brejauba, Minas Gerais, Brazil: description and crystal structure. American Mineralogist, 85:1822-1827.

Caraballo M.A., Michel F.M., Hochella Jr. M.F. 2015. The rapid expansion of environmental mineralogy in unconventional ways: Beyond the accepted definition of a mineral, the latest technology, and using nature as our guide. American Mineralogist, 100:14-25.

Čech F., Padera K, Povondra P. 1961. Lipscombite from pegmatites at Otov, near Domazlice (Bohemia, Czechoslovakia). Acta Universitatis Carolinae Geologica, 3:171-190.

Chao G.Y., Gault R.A. 1997. Quintinite-2H, quintinite-3T, charmarite$2 \mathrm{H}$, charmarite-3T and caresite-3T, a new group of carbonate minerals related to the hydrotalcite-manasseite group. Canadian Mineralogist, 35:1541-1549.

Chaves M.L.S.C. \& Karfunkel J. 1994. Novas ocorrências de euclásio em Minas Gerais. Boletim Instituto de Geociências, Universidade de São Paulo, Série Científica, 25:53-60.

Chopin C., Oberti R., Cámara F. 2006. The arrojadite enigma: II. Compositional space, new members and nomenclature of the group. American Mineralogist, 91:1260-1270.

Chukanov N.V., Atencio D., Zadov A.E., Menezes Filho L.A.D., Coutinho J.M.V. 2007. Guimarãesite, a new Zn-dominant monoclinic roscherite-group mineral from Itinga, Minas Gerais, Brazil. Novye Dannye o Mineralakh, 42:11-15 (in Russian), New Data on Minerals, 42:11-15 (in English).

Chukanov N.V., Rastsvetaeva R.K., Möckel St., Zadov A.E., Levitskaya L.A. 2006. The roscherite group and its new representative member atencioite, $\mathrm{Ca}_{2} \mathrm{Fe}^{2+} \square \mathrm{Mg}_{2} \mathrm{Fe}^{2+}{ }_{2} \mathrm{Be}_{4}\left(\mathrm{PO}_{4}\right)_{6}(\mathrm{OH})_{4} 6 \mathrm{H}_{2} \mathrm{O}$. Novye Dannye o Mineralakh, 41:18-25 (in Russian), New Data on Minerals, 41:1825 (in English).

Chukanov N.V., Scholz R., Zubkova N.V., Pekov I.V., Belakovskiy D.I., Van K.V., Lagoeiro L., Graça L.M., Krambrock K., Oliveira L.C.A., Menezes Filho L.A.D., Chaves M.L.S.C., Pushcharovsky D.Y. 2014. Correianevesite, $\mathrm{Fe}^{2+} \mathrm{Mn}^{2+}{ }_{2}\left(\mathrm{PO}_{4}\right)_{2} \cdot 3 \mathrm{H}_{2} \mathrm{O}$, a new reddingite-group mineral from the Cigana mine, Conselheiro Pena, Minas Gerais, Brazil. American Mineralogist, 99:811-816.

Clark A.M., Criddle A.J., Fejer E.E. 1974. Palladium arsenideantimonides from Itabira, Minas Gerais, Brazil. Mineralogical Magazine, 39:528-543.

Clark C.M., Hawthorne F.C., Grice J.D. 2010. Uvite, IMA 2000-030a. CNMNC Newsletter, April 2010, page 377; Mineralogical Magazine, 74;375-377.

Coltman R.W. 1924. The determination of manganese. Part II - Manganous oxalate as a primary standard. Industrial and Engineering Chemistry, 16(6):606-609.
Cooper M.A., Abdu Y.A., Ball N.A., Černý P., Hawthorne F., Kristiansen R. 2012. Aspedamite, ideally $\square_{12}\left(\mathrm{Fe}^{3+}, \mathrm{Fe}^{2+}\right)_{3} \mathrm{Nb}_{4}\left[\mathrm{Th}\left(\mathrm{Nb}, \mathrm{Fe}^{3+}\right)_{12} \mathrm{O}_{42}\right]$ $\left\{\left(\mathrm{H}_{2} \mathrm{O}\right),(\mathrm{OH})\right\}_{12}$, a new heteropolyniobate mineral species from the Herrebøkasa Quarry, Aspedammen, Østfold, Southern Norway: Description and crystal structure. Canadian Mineralogist, 50:793-804.

Damour A. 1884. Note sur un nouveau phosphate d'alumine et de chaux, des terrains diamantifères. Bulletin de la Société française de Minéralogie, 7:204-205.

Dana E.S. (1892) Dana's system of mineralogy. $6^{\text {th }}$ ed. New York, John Wiley \& Sons, 508-509.

Davis R.J., Clark A.M., Criddle A.J. 1977. Palladseïte, a new mineral from Itabira, Minas Gerais, Brazil. Mineralogical Magazine, 41:123 e M10-M13.0

Delamétherie J.C. 1792. New edition of Mongez's Sciagraphie. Paris, 2 v., 1:207,

Delamétherie J.C. 1797. Théorie de la Terre. 2 ed. Paris, 5 v., 2:113.

Donkova B., Pencheva J., Djarova M. 2004. Influence of complex formation upon inclusion of $\mathrm{Mn}(\mathrm{II}), \mathrm{Co}(\mathrm{II}), \mathrm{Ni}(\mathrm{II})$, and $\mathrm{Cu}(\mathrm{II})$ in $\mathrm{ZnC}_{2} \mathrm{O}_{4} \cdot 2 \mathrm{H}_{2} \mathrm{O}$. Crystal Research and Technology, 39(3):207-213.

Dunn P.J., Appleman D., Nelen J.A., Norberg J. 1977. Uvite, a new (old) common member of the tourmaline group and its implications to collectors. Mineralogical Record, 8:100-108.

Ercit T.S., Hawthorne F.C., Černý P. 1986. Parabariomicrolite, a new species, and its structural relationship to the pyrochlore group. Canadian Mineralogist, 24:655-663.

Eschwege W.L. 1822. Geognostisches Gemälde von Brasilien und wahrscheinliches Muttergestein der Diamanten. Landes-IndustrieComptoir, Weimar, $44 \mathrm{p}$.

Federico M., Andreozzi G.B., Lucchesi S., Graziani G., César-Mendes J. 1998. Crystal chemistry of tourmalines. I. Chemistry, compositional variations and coupled substitutions in the pegmatite dikes of the Cruzeiro mine, Minas Gerais, Brazil. Canadian Mineralogist, 36:415-431.

Foord E.E. \& Mrose M.E. 1978. Rynersonite, $\mathrm{Ca}(\mathrm{Ta}, \mathrm{Nb})_{2} \mathrm{O}_{6}$, A new mineral from San Diego Co., California. American Mineralogist, 63:709-714.

Foord E.E., Gaines R.V., Crock J.G., Simmons Jr.W.B., Barbosa C.P. 1986. Minasgeraisite, a new member of the gadolinite group from Minas Gerais, Brazil. American Mineralogist, 71:603-607.

Fourestier J. 2002. The naming of mineral species approved by the Commission on New Minerals and Mineral Names of the International Mineralogical Association: a brief history. Canadian Mineralogist, 40:1721-1735.

French R.A., Caraballo M.A., Kim B., Rimstidt J.D., Murayama M., Hochella Jr. M.F. 2012. The enigmatic iron oxyhydroxysulfate nanomineral schwertmannite: Morphology, structure, and composition. American Mineralogist, 97:1469-1482.

Gheith M.A. 1953. Lipscombite, a new synthetic "iron lazulite". American Mineralogist, 38:612-628.

Gorceix H. 1885. Estudos sobre a monazita e a xenotima no Brasil. Annaes da Escola de Minas de Ouro Preto, 4:29-48.

Guimarães D. 1924. Arrojadita, um novo mineral do grupo da wagnerita. Ministério da Viação e Obras Públicas, Inspectoria Federal de Obras Contra as Seccas, Rio de Janeiro. Publicação n. 58, p.119-122.

Hatert F., Baijot M., Philippo S., Wouters J. 2010 Q.ingheiite-( $\left.\mathrm{Fe}^{2+}\right)$, $\mathrm{Na}_{2} \mathrm{Fe}^{2+} \mathrm{MgAl}\left(\mathrm{PO}_{4}\right)_{3}$, a new phosphate mineral from the Sebastião Cristino pegmatite, Minas Gerais, Brazil. European Journal of Mineralogy, 22:459-467. 
Haüy R.J. 1798. Journal des Mines, 4, 5.

Hawthorne F.C. \& Henry D. 1999. Classification of the minerals of the tourmaline group. European Journal of Mineralogy, 11:201-215.

Hey M.H. 1955. An index of mineral species and varieties. London, British Museum.

Hoffmann C.A.S. 1789. Mineralsystem des Herrn Inspektor Werners mit dessen erlaubnis herausgegeben von C.A.S. Hoffmann, Bergmannisches Journal, 1:369-398.

Huizing A., Van Hal H.A.M., Kwestroo W., Langereis C., Van Loosdregt P.C. 1977. Hydrates of manganese (II) oxalate. Materials Research Bulletin, 12:605-611.

Hussak E. 1906. Über die sogenannten "Phosphat-Favas" der diamantführenden Sande Brasiliens. Tschermaks Mineralogishe und Petrographische Mitteilungen, Neue Folge, 25:335-344

Hussak E. 1907. Ueber Hussakit. Centralblatt für Mineralogie, Geologie und Palaeontologie, Jg., 533-536.

Hussak E. \& Prior G.T. 1895. Lewisite and zirkelite, two new Brazilian minerals. Mineralogical Magazine, 11:80-88

Hussak E. \& Prior G.T. 1897a. On derbylite, a new antimono-titanate of iron, from Tripuhy, Brazil. Mineralogical Magazine, 11:176-179.

Hussak H. \& Prior G.T. 1897b. On tripuhyite, a new antimonate of iron from Tripuhy, Brazil. Mineralogical Magazine, 11:302-303.

Hussak E. \& Prior G.T. 1898. On senaite, a new mineral belonging to the ilmenite group, from Brazil. Mineralogical Magazine, 12:30-32.

Hussak E. \& Prior G.T. 1900. Florencite, a new hydrated phosphate of aluminium and the cerium earths, from Brazil. Mineralogical Magazine, 12:244-248.

Jackson J.M. \& Burns P.C. 2001. A re-evaluation of the structure of weeksite, a uranyl silicate framework mineral. Canadian Mineralogist, 39:187-195.

Jedwab J. \& Cassedanne J. 1998. Historical observations on oxygenbearing compounds of platinum and palladium in Minas Gerais, Brazil. Canadian Mineralogist, 36:887-893.

Karsten D.L.G. 1789. Museum Leskeanum, Regnum minerale Leipzig, $2 \mathrm{v}$.

Kenngott G.A. 1853. Das Mohs'che Mineralsystem. Viena. p. 121.

Khomyakov A.P. 1998a. Mineralogy of hyperalkaline rocks: advances and prospects. 17th. General Meeting of the International Mineralogical Association, Toronto, Canada. Abstracts, A108.

Khomyakov A.P. 1998b. Recent mineral discoveries and the number of mineral species: a reconsideration. 17th. General Meeting of the International Mineralogical Association, Toronto, Canada. Abstracts, A156.

Khomyakov A.P. 2001. The distribution of minerals in hyperagpaitic rocks in terms of symmetry: evolution of views on the number and symmetry of minerals. Geology of Greenland Survey Bulletin, 190:73-82.

Klaproth M.H. 1795. Berträge zur chemischen Kenntniss der Mineralkörpers, 1:97

Kogarko L.N., Uvarova Yu. A., Sokolova E., Hawthorne F.C., Ottolini L., Grice J.D. 2005. Oxykinoshitalite, a new species of mica from Fernando de Noronha Island, Pernambuco, Brazil: occurrence and crystal structure. Canadian Mineralogist, 43:1501-1510.

Kolitsch U., Atencio D., Chukanov N.V., Zubkova N.V., Menezes Filho L.A.D., Coutinho J.M.V., Birch W.D., Schlüter J., Pohl D., Kampf A.R, Steele I.M., Favreau G., Nasdala L., Giester G., Pushcharovsky D. Yu. 2010.
Bendadaite, a new iron arsenate mineral of the arthurite group. Mineralogical Magazine, 74:469-486.

Kollia Z., Sarantopoulou E., Cefalas A.C., Nicolaides C.A., Naumov A.K., Semashko V.V., Abdulsabirov R.Y., Korableva S.L., Dubinskii M.A. 1995. Vacuum-ultraviolet interconfigurational $4 f 3 \rightarrow 4 f 25 d$ absorption and emission studies of the $\mathrm{Nd}^{3+}$ ion in KYF, YF, and YLF crystal hosts. Journal of the Optical Society of America B, 12:782-785.

Kraus E.H. \& Reitinger J. 1901. Hussakit, ein neues Mineral und dessen Beziehung zun Xenotim. Zeitschrift für Kristallographie und Mineralogie, 34:268-277

Kunitz W. 1929. Die Mischungsreihen in der Turmalingruppe und die genetischen Beziehungen zwischen Turmalinen und Glimmern. Chemie der Erde, 4:208-251.

Lage M.M., Righi A., Matinaga F.M., Gesland J-Y, Moreira R.L. 2004 Raman-spectroscopic study of lanthanide trifluorides with the $\beta-\mathrm{YF}_{3}$ structure. Journal of Physics: Condensed Matter, 16:3207-3218.

Leavens P.B., White J.S., Nelen J.A. 1990. Zanazziite, a new mineral from mineral from Minas Gerais, Brazil. Mineralogical Record, 21:413-417

Leonardos O.H. 1945. Ocorrências de crisoberilo no Brasil. Mineração e Metalurgia, 9:29-31

Leonardos O.H. 1970. Geociências no Brasil: a Contribuição Britânica. Editora Forum. 343 p.

Lindberg M.L. 1949. Frondelite and the frondelite-rockbridgeite series. American Mineralogist, 34:541-549.

Lindberg M.L. 1962. Manganoan lipscombite from the Sapucaia Pegmatite Mine, Minas Gerais, Brazil, first occurrence of lipscombite in nature. American Mineralogist, 47:353-359.

Lindberg M.L. \& Murata K.J. 1953. Faheyite, a new phosphate mineral from the Sapucaia pegmatite mine, Minas Gerais, Brazil. American Mineralogist, 38:263-270, 349

Lindberg M.L. \& Pecora W.T. 1955. Tavorite and barbosalite, two new phosphate minerals from Minas Gerais, Brazil. American Mineralogist, 40:952-966.

Lindberg M.L. \& Pecora W.T. 1958. Phosphate minerals from Sapucaia Pegmatite Mine, Minas Gerais. Boletim da Sociedade Brasileira de Geologia, 7(2):5-14

Lindberg M.L., Pecora W.T., Barbosa A.L.M. 1953. Moraesite a new hydrous beryllium phosphate form Minas Geris, Brazil. American Mineralogist, 38:1126-1133.

Lindström G. 1910. Om lantaniten. Geologiska Föreningen i Stockholm Förhandlingar, 32: 206-214

Menezes Filho L.A.D., Atencio D., Andrade M.B., Downs T.T., Chaves M.L.S.C., Romano A.W., Scholz R., Persiano A.I.C. 2015. Pauloabibite, trigonal $\mathrm{NaNbO}_{3}$, isostructural with ilmenite, from the Jacupiranga carbonatite, Cajati, São Paulo, Brazil. American Mineralogist, 100:442-446.

Menezes Filho L.A.D., Chukanov N.V., Rastsvetaeva R.K., Aksenov S.M., Pekov I.V., Chaves M.L.S.C., Scholz R., Atencio D., Brandão P.R.G., Romano A.W., De Oliveira L.C.A., Ardisson J.D., Krambrock K., Moreira R.L., Guimarães F.S., Persiano A.C, Richards R.P. 2013. Almeidaite, IMA 2013-020. CNMNC Newsletter n. 16, 2013, p. 2705; Mineralogical Magazine, 77:2695-2709.

Modeshia D.R., Darton R.J., Ashbrook S.E., Walton R.I. 2009. Control of polymorphism in $\mathrm{NaNbO}_{3}$ by hydrothermal synthesis. Chemical Communications, 45(1):68-70.

Moore P.B., Barbosa C.P., Gaines R.V. 1978. Bahianite, $\mathrm{Sb}_{3} \mathrm{Al}_{5} \mathrm{O}_{14}(\mathrm{OH})_{2}$, a new species. Mineralogical Magazine, 42:179-182. 
Moore P.B. \& Ito J. 1978. I. - Whiteite, a new species, and a proposed nomenclature for jahnsite-whiteite complex series. II. - New data on xanthoxenite. III. -Salmonsite discredited. Mineralogical Magazine, 42:309-323.

Moore P.B. \& Ito J. 1979. Alluaudites, wyllieites, arrojadites: crystal chemistry and nomenclature. Mineralogical Magazine, 43:227-235.

Nickel E.H. 1995. The definition of a mineral. Canadian Mineralogist, 33:689-690.

Nickel E.H. \& Grice J.D. 1998. The IMA Commission on New Minerals and Mineral Names: procedures and guidelines on mineral nomenclature, 1998. Canadian Mineralogist, 36:913-926.

Nickel E.H. \& Mandarino J.A. 1987. Procedures involving the IMA Commission on New Minerals and Mineral Names and guidelines on mineral nomenclature. American Mineralogist, 72:1031-1042.

Nomura S.F., Atencio D., Chukanov N.V., Rastsvetaeva R.K., Coutinho J.M.V., Karipidis T.K. 2010. Manganoeudialyte - a new mineral from Poços de Caldas, Minas Gerais, Brazil. Zapiski Vserossiiskogo Mineralogicheskogo Obshestva (Proceedings of the Russian Mineralogical Society), 139(4):35-47.

Nyman M., Bonhomme F., Alam T.M., Rodriguez M.A., Cherry B.R., Krumhansl J.L., Nenoff T.M., Sattler A.M. 2002. A general synthetic procedure for heteropolyniobates. Science, 297:996-998.

Nyman M., Bonhomme F., Alam T.M., Parise J.B., Vaughan G.M.B. 2004. $\left[\mathrm{SiNb}_{12} \mathrm{O}_{40}\right]^{16-}$ and $\left[\mathrm{GeNb}_{12} \mathrm{O}_{40}\right]^{16-}$ : Highly charged Keggin ions with sticky surfaces. Angewandte Chemie International Edition, 43:2787-2792

Pecora W.T. \& Fahey J.J. 1949. The Córrego Frio pegmatite, Minas Gerais: scorzalite and souzalite, two new phosphate minerals. American Mineralogist, 34:83-93.

Pough F.H. \& Henderson E.P. 1945. Brazilianite, a new phosphate mineral. American Mineralogist, 30:572-582.

Roberts A.C, Chao G.J., Cesbron F. 1980. Lanthanite-(Nd), a new mineral from Curitiba, Paraná, Brazil. Geological Survey of Canada, 80-1C:141-142.

Romé de l'Isle J.B.L. 1772. Essais de cristallographie. Paris.

Rösler H. 1902. Über Hussakit (Xenotim) und einige andere gesteinsbildende Mineralien. Zeitschrift für Kristallographie (Leipzig), 36:258-267.
Scholz R., Chukanov N.V., Menezes Filho L.A.D., Atencio D., Lagoeiro L., Belotti F.M., Chaves M.L.S.C., Romano A.W., Brandão P.R., Belakovskiy D.I., Pekov I. 2014. Césarferreiraite, $\mathrm{Fe}^{2+} \mathrm{Fe}^{3+}{ }_{2}\left(\mathrm{AsO}_{4}\right)_{2}(\mathrm{OH})_{2} \cdot 8 \mathrm{H}_{2} \mathrm{O}$, from Eduardo mine, Conselheiro Pena, Minas Gerais, Brazil: Second arsenate in the laueite mineral group. American Mineralogist, 99:607-611.

Seybert H. 1824. Analyses of chrysoberyls from Haddam and Brazil. American Journal of Science and Arts, New Haven, Series 1, 8(1):105-112.

Shepard C.U. 1857. Treatise on Mineralogy. 3rd. ed. v. 2, p. 408.

Skinner B.J. \& Skinner C.W. 1980. Is there a limit to the number of minerals? Mineralogical Record, 11:333-335.

Thompson R.M. 1949. The telluride minerals and their occurrence in Canada. American Mineralogist, 34:342-382.

Vymazalová A., Laufek F., Drábek M., Cabral A.R., Haloda J., Sidorinová T., Lehmann B., Galbiatti H.F., Drahokoupil J. 2012. Jacutingaite, $\mathrm{Pt}_{2} \mathrm{HgSe}_{3}$, a new platinum-group mineral from the Cauê iron-ore deposit, Itabira District, Minas Gerais, Brazil. Canadian Mineralogist, 50:431-440.

Witzke T., Steins M., Doering T., Schuckmann W., Wegner R., Pöllmann H. 2011. Fluornatromicrolite, $(\mathrm{Na}, \mathrm{Ca}, \mathrm{Bi})_{2} \mathrm{Ta}_{2} \mathrm{O}_{6} \mathrm{~F}$, a new mineral species from Quixaba, Paraíba, Brazil. Canadian Mineralogist, 49:1105-1110.

Witzke T, Wegner R, Doering T, Pöllmann H, Schuckmann W. 2000. Serrabrancaite, $\mathrm{MnPO}_{4} \cdot \mathrm{H}_{2} \mathrm{O}$, a new mineral from the Alto Serra Branca pegmatite, Pedra Lavrada, Paraiba, Brazil. American Mineralogist, 85:847-849.

Wollaston W.H. 1809. On platina and native palladium from Brasil. Philosophical Transactions Royal Society London, 99:189-194.

Wu S.Y., Zhang W., Chen X.M. 2010. Formation mechanism of $\mathrm{NaNbO}_{3}$ powders during hydrothermal synthesis. Journal of Materials Science: Materials in Electronics, 21:450-455.

Yang H., Downs R.T., Evans S.H., Morrison S.M., Schumer B.M. 2015. Lefontite, IMA 2014-075. CNMNC Newsletter n. 23, February 2015, p. 55; Mineralogical Magazine, 79:51-58.

$\overline{\text { Arquivo digital disponível on-line no site www.sbgeo.org.br }}$ 